\title{
The Impact of Muscarinic Receptor Antagonists on Airway Inflammation: A Systematic Review
}

This article was published in the following Dove Press journal:

International Journal of Chronic Obstructive Pulmonary Disease

\author{
Luigino Calzetta $\mathbb{D}^{\prime}$ \\ Angelo Coppola ${ }^{2}$ \\ Beatrice Ludovica Ritondo ${ }^{3}$ \\ Matteo Matino ${ }^{3}$ \\ Alfredo Chetta' \\ Paola Rogliani $\mathbb{D}^{2,3}$ \\ 'Department of Medicine and Surgery, \\ Respiratory Disease and Lung Function \\ Unit, University of Parma, Parma, Italy; \\ ${ }^{2}$ Division of Respiratory Medicine, \\ University Hospital "Policlinico Tor \\ Vergata", Rome, Italy; ${ }^{3}$ Unit of \\ Respiratory Medicine, Department of \\ Experimental Medicine, University of \\ Rome "Tor Vergata", Rome, Italy
}

Correspondence: Paola Rogliani Department of Experimental Medicine, University of Rome "Tor Vergata", Via

Montpellier I, Rome 00133, Italy

Tel +390620904656

Email paola.rogliani@uniroma2.it

\begin{abstract}
Long-acting muscarinic receptor antagonists (LAMAs) are the cornerstone for the treatment of chronic obstructive pulmonary disease (COPD); furthermore, tiotropium is approved as add-on therapy in severe asthmatic patients. Accumulating evidence suggests that LAMAs may modulate airway contractility and airway hyperresponsiveness not only by blocking muscarinic acetylcholine receptors (mAchRs) expressed on airway smooth muscle but also via anti-inflammatory mechanisms by blocking mAchRs expressed on inflammatory cells, submucosal glands, and epithelial cells. The aim of this systematic review, performed according to the PRISMA-P guidelines, was to provide a synthesis of the literature on the anti-inflammatory impact of muscarinic receptor antagonists in the airways. Most of the current evidence originates from studies on tiotropium, that demonstrated a reduction in synthesis and release of cytokines and chemokines, as well as the number of total and differential inflammatory cells, induced by different pro-inflammatory stimuli. Conversely, few data are currently available for aclidinium and glycopyrronium, whereas no studies on the potential anti-inflammatory effect of umeclidinium have been reported. Overall, a large body of evidence supports the beneficial impact of tiotropium against airway inflammation. Further well-designed randomized controlled trials are needed to better elucidate the antiinflammatory mechanisms leading to the protective effect of LAMAs against exacerbations via identifying suitable biomarkers.
\end{abstract}

Keywords: muscarinic receptor antagonist, LAMA, tiotropium, inflammation, systematic review

\section{Introduction}

Long-acting muscarinic receptor antagonists (LAMAs) are central to the maintenance treatment of stable chronic obstructive pulmonary disease (COPD). ${ }^{1}$ Furthermore, tiotropium bromide (TIO) is approved as add-on therapy in severe asthmatic patients with a history of exacerbations at Steps 4 and 5.,3

Airflow restriction, along with small airway involvement, and pathological structural changes in the airways are hallmark features of chronic obstructive respiratory disorders. COPD and asthma may share some symptoms and clinical characteristics; however, these disorders are characterized by specific pathophysiological patterns, and the mechanism of bronchospasm is generally different: mainly hyperinflation in COPD and airway hyperresponsiveness (AHR) in asthma. Moreover, symptoms and clinical presentation in COPD may be caused by a dysfunction of the autonomic nerve control of the airway smooth muscle (ASM) tone. ${ }^{4}$ Vagal innervation is the main cause of the bronchoconstrictive airway responses and represents the reversible component of airflow obstruction, thus 
making muscarinic receptor antagonists effective in the management of chronic obstructive airway disorders. ${ }^{5,6}$ Up-regulation of acetylcholine (Ach) release is associated with increased ASM contractility, mucus hypersecretion, and enhanced parasympathetic tone in airway inflammation of both COPD and asthma. ${ }^{6}$ Muscarinic Ach receptor ( $m$ AchR) subtypes $\left(\mathrm{M}_{1}, \mathrm{M}_{2}\right.$ and $\left.\mathrm{M}_{3}\right)$, widely expressed in the airways, are involved in airway remodelling and inflammation. ${ }^{6}$

Accumulating evidence has indicated that LAMAs may modulate airway contractility and AHR not only by blocking mAchRs expressed on the ASM but also via antiinflammatory mechanisms by blocking mAchRs expressed on inflammatory cells, submucosal glands, and epithelial cells. ${ }^{7,8}$ Moreover, non-neuronal Ach released from airway epithelium modulates ASM contractility in small airways and potentially also inflammation, with LAMAs preventing these detrimental effects. ${ }^{9}$

To date, no systematic reviews on the antiinflammatory effect of muscarinic receptor antagonists have been performed in respiratory medicine. Therefore, the aim of this systematic review was to provide a synthesis of the literature on the anti-inflammatory impact of muscarinic receptor antagonists in the airways.

\section{Materials and Methods}

Detailed methods are reported in the Supplementary Appendix.

\section{Review Question}

To assess the impact of muscarinic receptor antagonists on airway inflammation.

\section{Search Strategy and Study Eligibility}

This qualitative synthesis of the current literature was performed in agreement with the Preferred Reporting Items for Systematic Reviews and Meta-Analyses Protocols (PRISMA-P, submission ID: 170285). ${ }^{10}$ The flow diagram is reported in Supplementary Figure 1 and the PRISMA-P checklist in Supplementary Table 1.

A comprehensive literature search was performed for in vitro, in vivo, and clinical studies, written in English and evaluating the impact of muscarinic receptor antagonists on airway inflammation. The search was performed in MEDLINE in order to provide reports available from the last decade up to 5th June, 2020 for in vitro and in vivo studies; clinical studies were searched with no time limitation. The research string was as follows: (((muscarinic antagonists) OR antimuscarinic OR tiotropium OR glycopyrronium OR umeclidinium OR aclidinium OR ipratropium OR oxitropium) AND inflammation) NOT review.

\section{Study Selection}

In vitro, in vivo, and clinical studies reporting the impact of muscarinic receptor antagonists on airway inflammation were included in this systematic review. Research papers evaluating the anti-inflammatory activity of muscarinic receptor antagonists in combination with other therapeutic agents were excluded.

\section{Data Extraction}

Data from included studies were extracted and checked for study and year of publication, type of study, type of cells, animals, and donors, pro-inflammatory stimuli, number of patients or donors or animals, gender, treatments, route of administration, type of biological samples, and investigated outcomes.

\section{Endpoints}

The endpoint of this systematic review was the impact of muscarinic receptor antagonists on airway inflammation.

\section{Strategy for Data Analysis}

Data from original papers were extracted and reported via qualitative synthesis.

\section{Quality of Studies and Risk of Bias}

The summary of the risk of bias for each included clinical study was analyzed via the Jadad score and the Cochrane Risk of Bias 2 (RoB 2). ${ }^{11,12}$

\section{Results}

Of the 268 potentially relevant records identified in the initial search, 49 studies were deemed eligible for a qualitative analysis (Supplementary Table 2). Detailed information concerning the study characteristics and the pro-inflammatory stimuli used in the included studies are described in the Supplementary Appendix.

\section{Anti-Inflammatory Effect of Muscarinic Receptor Antagonists in vitro}

An overview concerning the anti-inflammatory effect of muscarinic receptor antagonists in vitro is reported in Table 1. 


\section{Tiotropium Bromide}

In immortalized 16HBE human bronchial epithelial cells stimulated by cigarette smoke (CS) extract (CSE), TIO $100 \mathrm{nM}$ reduced the over-expression of interleukin (IL)-8. ${ }^{13}$ TIO also inhibited the gene and protein over-expression of IL-8, reduced the transloca-

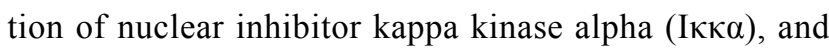
improved the expression and activity of histone deacetylase 2 (HDAC2) following simulation with the supernatant of sputum collected from COPD patients or recombinant human IL-17A. ${ }^{14}$ TIO suppressed the neutrophil adhesion to epithelial cells after stimulation with supernatant of the sputum collected from COPD patients, tumor growth factor-beta 1 (TGF- $\beta 1$ ), and/or Ach, by inhibiting the over-expression of macrophage1 antigen (MAC-1). ${ }^{15}$

TIO $33 \mathrm{pM}$, corresponding to the plasma concentration after inhalation of TIO $18 \mu \mathrm{g}$, reduced the infectioninduced release of IL-1 $\beta$, IL- 6 , and IL-8 in human tracheal surface epithelial cells derived from either healthy or COPD patients stimulated with rhinovirus type-14 infection. ${ }^{16}$

In immortalized BEAS-2B human bronchial epithelial cells stimulated with lipopolysaccharide (LPS), TIO inhibited the gene and protein over-expression of IL-8, and suppressed the increased activity of nuclear factor- $\kappa \mathrm{B}(\mathrm{NF}-\mathrm{\kappa B})$ via inactivating $\mathrm{p} 50$ and $\mathrm{p} 65$ subunits. ${ }^{17}$

TIO $10 \mathrm{nM}-1 \mu \mathrm{M}$ reduced the release of IL- 8 but not of IL-6 from lung fibroblasts stimulated by IL- $1 \beta$. After stimulation with both IL-1 $\beta$ and carbachol (Cch), TIO counteracted the over-expression of both IL- 6 and IL- $8 .{ }^{18}$ TIO reduced the increased release and activity of matrix metalloproteinase (MMP)-1 and MMP-2 induced by TGF$\beta$, but did not modulate the gene over-expression of tissue inhibitor of metalloproteinases (TIMP)-1 and TIMP-2. ${ }^{19}$ TIO also reduced the gene over-expression of IL-8 and suppressed the increased activity of NF-KB induced by LPS stimulation. ${ }^{17}$

TIO $30 \mathrm{nM}$ inhibited the neutrophil migration rate and tumor necrosis factor-alpha (TNF- $\alpha$ ) release following a challenge with the supernatant from alveolar macrophages derived from COPD patients and stimulated by LPS. Conversely, TIO showed no modulatory effect on IL-6, IL-8, leukotriene B4 (LTB 4 ), granulocyte-macrophage colony-stimulating factor (GM-CSF), and macrophage inflammatory protein (MIP)- $\alpha /-\beta .^{20} \mathrm{In}$ neutrophils stimulated with the supernatant of the sputum collected from COPD patients TIO $100 \mathrm{nM}$ reduced the over-expression of MAC-1. ${ }^{15}$ TIO $20 \mathrm{nM}$ increased the percentage of apoptotic CD3+ and CD8+ peripheral blood $\mathrm{T}$ (PBT)-cells isolated from COPD patients and improved the proteolytic activity of caspases 3 and 8. TIO also reduced the number of apoptotic CD4+ cells, and blocked the phosphorylation of

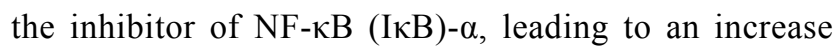

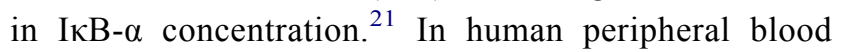
mononuclear cells isolated from asthmatic patients stimulated with phytohemagglutinin (PHA), the overrelease of IL-5 and IL-13 was suppressed by TIO 1$100 \mu \mathrm{g} / \mathrm{mL}$, without affecting the level of IL-4. ${ }^{22}$ In spleen cells derived from mice and stimulated with ovalbumin (OVA), TIO $50 \mu \mathrm{g} / \mathrm{mL}$ inhibited the overexpression of IL-5, IL-13, and interferon-gamma $(\mathrm{IFN}-\gamma){ }^{22}$

\section{Aclidinium}

In human 16HBE immortalized bronchial epithelial cells, aclidinium (ACL) $10 \mathrm{nM}$ did not counteract the CSEmediated protein and gene over-expression of IL-8, and the reduced nuclear expression of sirtuin 1, HDAC2, and HDAC $3 .^{23}$

ACL $0.1 \mathrm{nM}-1 \mu \mathrm{M}$ decreased the release of IL- $1 \beta$, IL8, MMP-9, C-C motif chemokine ligand 5, and GM-CSF, but did not modulate the expression of HDAC2 in neutrophils from stable COPD patients exposed to CSE or challenged with LPS. ${ }^{24}$

\section{Glycopyrronium Bromide}

In human primary bronchial epithelial cells, glycopyrronium (GLY) $100 \mathrm{nM}$ suppressed the gene and protein over-expression of IL-8 induced by CSE and Ach. ${ }^{25}$

\section{Ipratropium Bromide}

Ipratropium bromide (IB) $30 \mathrm{nM}$ did not modify the migration rate of neutrophils following a challenge with the supernatant from alveolar macrophages derived from COPD patients and stimulated by LPS. ${ }^{20}$

\section{I, I-Dimethyl-4-Diphenylacetoxypiperidinium lodide}

1,1-dimethyl-4-diphenylacetoxypiperidinium iodide (4-DAMP) $10-100 \mu \mathrm{M}$ inhibited the release of TNF- $\alpha$ and the degradation of IKB- $\alpha$ in alveolar macrophages challenged with LPS. $^{26}$ 4-DAMP also reduced the migration rate of neutrophils following a challenge with the supernatant from alveolar macrophages 
Table I Impact of Muscarinic Receptor Antagonists on Humoral and Cellular Responses Upon Induction of a Pro-Inflammatory Stimulus in vitro. Statistically Significant Results with a $\mathrm{P}<0.05$ are Reported in the Table

\begin{tabular}{|c|c|c|c|c|c|c|c|c|c|c|c|c|c|}
\hline \multirow{2}{*}{$\begin{array}{l}\text { Investigated } \\
\text { Treatment }\end{array}$} & \multirow{2}{*}{$\begin{array}{l}\text { Pro- } \\
\text { Inflammatory } \\
\text { Stimulus }\end{array}$} & \multicolumn{12}{|c|}{ Outcomes Investigated in the in vitro Studies } \\
\hline & & IL-I $\beta$ & IL-4 & IL-5 & IL-6 & IL-8 & IL-13 & IFN- $\gamma$ & TNF- $\alpha$ & $\begin{array}{l}\text { HDAC } \\
\text { Activity }\end{array}$ & SIRTI & $\begin{array}{l}\text { NF-кB } \\
\text { Activity }\end{array}$ & CCL5 \\
\hline \multirow[t]{3}{*}{$\mathrm{ACL}$} & CSE & l & I & l & l & $\approx^{23}, \downarrow^{24}$ & l & I & I & $\approx^{23}$ & $\approx^{23}$ & l & l \\
\hline & LPS & $\downarrow^{24}$ & I & l & l & $\downarrow^{24}$ & l & I & I & $\approx^{24}$ & l & l & $\downarrow^{24}$ \\
\hline & Cch & l & I & l & l & $\downarrow^{24}$ & l & I & I & I & I & I & l \\
\hline \multirow[t]{2}{*}{ GLY } & CSE & l & I & I & l & $\downarrow^{25}$ & I & l & I & l & l & I & l \\
\hline & Ach & l & I & l & I & $\downarrow^{25}$ & l & I & I & I & I & I & I \\
\hline \multirow[t]{13}{*}{ TIO } & CSE & I & I & I & 1 & $\downarrow^{13}$ & I & I & I & l & I & I & I \\
\hline & $\begin{array}{l}\text { Supernatant of } \\
\text { the sputum of } \\
\text { COPD patients }\end{array}$ & I & I & I & 1 & $\downarrow^{14}$ & 1 & I & I & $\uparrow^{14}$ & I & $\downarrow^{14}$ & I \\
\hline & rhIL-I7A & I & I & I & I & $\downarrow^{14}$ & I & I & I & $\uparrow^{14}$ & I & $\downarrow^{14}$ & I \\
\hline & IL-I $\beta$ & I & I & I & $\approx^{18}$ & $\downarrow^{18}$ & I & I & I & I & I & I & I \\
\hline & IL-I $\beta$ and Cch & I & I & I & $\downarrow^{18}$ & $\downarrow^{18}$ & I & I & I & l & I & I & I \\
\hline & Ach & I & I & I & I & I & I & I & I & l & I & I & I \\
\hline & $\begin{array}{l}\text { Ach and TGF- } \\
\beta I\end{array}$ & I & I & I & I & I & l & I & I & I & I & I & l \\
\hline & TGF- $\beta$ & I & I & I & I & 1 & I & I & I & I & I & I & I \\
\hline & LPS & I & I & I & $\approx^{20}$ & $\downarrow^{17}, \approx^{20}$ & I & I & $\downarrow^{20}$ & I & I & $\downarrow^{17}$ & I \\
\hline & PHA & I & $\approx^{22}$ & $\downarrow^{22}$ & 1 & I & $\downarrow^{22}$ & I & I & I & I & I & I \\
\hline & OVA & I & I & $\downarrow^{22}$ & I & I & $\downarrow^{22}$ & $\downarrow^{22}$ & I & I & I & I & I \\
\hline & $\begin{array}{l}\text { Rhinovirus } \\
\text { type-14 }\end{array}$ & $\downarrow^{16}$ & I & I & $\downarrow^{16}$ & $\downarrow 16$ & 1 & I & I & I & I & I & I \\
\hline & NA & I & I & I & I & I & I & I & I & I & I & $\downarrow^{21}$ & I \\
\hline
\end{tabular}




\begin{tabular}{|c|c|c|c|c|c|c|c|c|c|c|c|}
\hline $\begin{array}{l}\text { GM- } \\
\text { CSF }\end{array}$ & $\begin{array}{l}\text { Proteolytic } \\
\text { Caspase } \\
\text { Activity }\end{array}$ & $\begin{array}{l}\text { Total } \\
\text { Inflammatory } \\
\text { Cells }\end{array}$ & Neutrophils & $\begin{array}{l}\text { Apoptotic } \\
\text { CD+T } \\
\text { Cells }\end{array}$ & LTB $_{4}$ & $\begin{array}{l}\text { MIP } \\
\alpha / \beta\end{array}$ & $\begin{array}{l}\text { MMP. } \\
\text { I }\end{array}$ & $\begin{array}{l}\text { MMP. } \\
2\end{array}$ & $\begin{array}{l}\text { MMP. } \\
9\end{array}$ & $\begin{array}{l}\text { TIMP. } \\
\text { I }\end{array}$ & $\begin{array}{l}\text { TIMP- } \\
2\end{array}$ \\
\hline I & I & I & I & I & I & I & I & I & I & I & I \\
\hline$\downarrow^{24}$ & I & I & I & I & I & I & I & I & $\downarrow^{24}$ & l & l \\
\hline 1 & I & I & I & I & I & I & I & 1 & I & I & I \\
\hline I & I & I & I & I & I & I & I & I & I & I & I \\
\hline 1 & I & I & I & I & I & I & I & I & I & I & I \\
\hline I & I & I & I & 1 & I & I & I & I & I & I & I \\
\hline I & 1 & I & $\begin{array}{l}\downarrow \text { percentage of } \\
\text { adhering } \\
\text { neutrophils, MAC-I } \\
\text { expression on } \\
\text { neutrophils }^{15}\end{array}$ & I & I & I & I & 1 & I & 1 & I \\
\hline 1 & I & I & I & 1 & I & I & I & I & I & I & I \\
\hline I & I & I & I & I & I & I & I & I & I & I & I \\
\hline l & I & I & I & 1 & I & I & I & l & I & I & I \\
\hline 1 & I & I & $\begin{array}{l}\downarrow \text { percentage of } \\
\text { adhering } \\
\text { neutrophils, MAC-I } \\
\text { expression on } \\
\text { neutrophils }^{15}\end{array}$ & I & I & 1 & 1 & 1 & 1 & I & 1 \\
\hline 1 & I & I & $\begin{array}{l}\downarrow \text { percentage of } \\
\text { adhering } \\
\text { neutrophils, MAC-I } \\
\text { expression on } \\
\text { neutrophils }^{15}\end{array}$ & I & I & 1 & 1 & 1 & I & 1 & I \\
\hline I & I & I & 1 & 1 & I & I & $\downarrow^{19}$ & $\downarrow^{19}$ & 1 & $\approx^{19}$ & $\approx^{19}$ \\
\hline$\approx^{20}$ & I & I & $\downarrow^{20}$ & I & $\approx^{20}$ & $\approx^{20}$ & I & I & I & I & I \\
\hline 1 & I & I & I & I & I & 1 & 1 & 1 & I & I & 1 \\
\hline I & I & I & I & I & I & I & I & I & I & I & I \\
\hline 1 & I & I & I & I & I & I & I & 1 & I & 1 & I \\
\hline I & $\begin{array}{l}\uparrow \text { caspase } 3 \\
\text { and } 8^{21}\end{array}$ & I & I & $\begin{array}{l}\uparrow \mathrm{CD} 3+ \\
\text { and CD8 } \\
+^{21} \\
\downarrow \mathrm{CD} 4+^{21}\end{array}$ & I & I & I & 1 & I & I & 1 \\
\hline
\end{tabular}

(Continued) 
Table I (Continued).

\begin{tabular}{|c|c|c|c|c|c|c|c|c|c|c|c|c|c|}
\hline \multirow{2}{*}{$\begin{array}{l}\text { Investigated } \\
\text { Treatment }\end{array}$} & \multirow{2}{*}{$\begin{array}{l}\text { Pro- } \\
\text { Inflammatory } \\
\text { Stimulus }\end{array}$} & \multicolumn{12}{|c|}{ Outcomes Investigated in the in vitro Studies } \\
\hline & & IL-I $\beta$ & IL-4 & IL-5 & IL-6 & IL-8 & IL-13 & IFN- $\gamma$ & TNF- $\alpha$ & $\begin{array}{l}\text { HDAC } \\
\text { Activity }\end{array}$ & SIRTI & $\begin{array}{l}\text { NF-кB } \\
\text { Activity }\end{array}$ & CCL5 \\
\hline \multirow[t]{2}{*}{ 4-DAMP } & OVA & I & $\approx^{22}$ & $\downarrow^{22}$ & 1 & I & $\downarrow^{22}$ & $\downarrow^{22}$ & I & l & I & 1 & I \\
\hline & LPS & l & l & l & l & l & l & l & $\downarrow^{26}$ & l & l & $\downarrow^{26}$ & l \\
\hline IB & LPS & l & l & l & l & 1 & 1 & I & I & 1 & I & 1 & I \\
\hline
\end{tabular}

Abbreviations: Ach, acetylcholine; ACL, aclidinium; Cch, carbachol; COPD, chronic obstructive pulmonary disease; CSE, cigarette smoke extract; GLY, glycopyrronium; HDAC, histone deacetylase; IB, ipratropium bromide; IFN, interferon; IL, interleukin; LPS, lipopolysaccharide; MAC-I, macrophage-I antigen; MIP, macrophage inflammatory protein; MMP, matrix metalloproteinase; NA, not available; NF-kB, nuclear factor kappa-light-chain-enhancer of activated B cells; NLF, nasal lavage fluid; OVA, ovalbumin; PHA, phytohemagglutinin; rhIL-I7A, recombinant human IL-I7A; SIRTI, sirtuin I; TGF- $\beta$ I, tumor growth factor-beta I; TIMP, tissue inhibitor of metalloproteinase; TIO, tiotropium bromide or tiotropium bromide hydrate; TNF- $\alpha$, tumor necrosis factor-alpha; 4-DAMP, I,I-dimethyl-4-diphenylacetoxypiperidinium iodide.

derived from COPD patients and stimulated by LPS. $^{20}$ In spleen cells derived from mice and stimulated with OVA, 4-DAMP 5-100 $\mu \mathrm{g} / \mathrm{mL}$ reduced the over-release of IL-5, IL-13, and IFN- $\gamma$, with no modulatory effect on $\mathrm{IL}-4 .^{22}$

\section{Anti-Inflammatory Effect of Muscarinic Receptor Antagonists in Laboratory Animals}

An overview concerning the anti-inflammatory effect of muscarinic receptor antagonists in laboratory animals is reported in Tables 2 and 3 .

\section{Tiotropium Bromide}

In BALB/cAnNCrl mice exposed to $\mathrm{CS}$ and infected with H1N1 influenza virus, nebulized TIO $0.1-0.3 \mathrm{mg} / \mathrm{mL}$ reduced the over-expression of IL- $1 \beta$, IL- 6 , IFN- $\gamma$, and TNF- $\alpha$ in lung tissue, and the number of total inflammatory cells, neutrophils, and macrophages in bronchoalveolar lavage fluid (BALf), with no effect on keratinocyte-derived chemokine $(\mathrm{KC} / \mathrm{CXCL} 1){ }^{27}$ In $\mathrm{BALB} / \mathrm{c}$ mice exposed to $\mathrm{CS}$ and infected with respiratory syncytial virus, TIO reduced the number of neutrophils and decreased the levels of IL-6, IFN- $\gamma$, TNF- $\alpha$, and $\mathrm{KC}$ in lung tissue, but did not modulate the level of macrophages in BALf. ${ }^{27}$ In ICR mice exposed to CS, TIO $60 \mu \mathrm{g} / \mathrm{mL}$ via aerosol reduced the level of total inflammatory cells, neutrophils, macrophages, and lymphocytes, and the gene and protein over-expression of IL$1 \beta$, KC, monocyte chemoattractant protein (MCP-1), TGF- $\beta 1$, and TNF- $\alpha$ in BALf and lung tissue. ${ }^{28,29}$ TIO also modulated the upregulation of MMP-9 and TIMP-1. ${ }^{29}$ In $\mathrm{C} 57 \mathrm{Bl} / 6 \mathrm{~J}$ mice exposed to $\mathrm{CS}$, TIO
$0.1 \mathrm{mg} / \mathrm{mL}-0.3 \mathrm{mg} / \mathrm{mL}$ via inhalation reduced the number of total inflammatory cells and neutrophils in lung tissue and BALf, with no modulatory effect on monocytic cell count. TIO also inhibited the release of $\mathrm{KC}$, and the over-expression of IL-6, MCP-1, MIP-2, MIP-1 $\alpha$, TNF $\alpha$, and $\mathrm{LTB}_{4}(-94.00 \%)$ in BALf. ${ }^{30}$ In CS-exposed domestic cats, inhalation of TIO $18 \mu \mathrm{g}$ reduced the increased concentrations of serum total protein, with no modulatory effect on the total leukocyte and differential cell counts in the blood. At the BALf level, TIO reduced the overexpression of IL-6, IL-8, MCP-1, and TNF- $\alpha$, and the number of total inflammatory cells, macrophages, and eosinophils, but not neutrophils and lymphocytes. TIO suppressed perivascular and peribronchiolar infiltration of inflammatory cells in lung tissues and improved the lung inflammation scores. ${ }^{31}$

In $\mathrm{C} 57 \mathrm{Bl} / 6$ mice challenged with LPS, aerosolized TIO $0.1 \mathrm{mg} / \mathrm{mL}-0.3 \mathrm{mg} / \mathrm{mL}$ reduced the total number of inflammatory cells and inhibited the release of IL-6 in BALf. No effect on neutrophils and monocytes counts, and on TNF $\alpha$, MIP-2, MCP-1, and MIP-1 $\alpha$ were detected. ${ }^{30}$ In Hartley guinea pigs challenged with LPS, nebulized TIO $0.1 \mathrm{mM}$ inhibited neutrophilia in the airways and parenchyma. ${ }^{32}$

In $\mathrm{C} 57 \mathrm{BL} / 6 \mathrm{~J}$ mice challenged with house dust mite extract, intranasal treatment with TIO $1 \mathrm{mg} / \mathrm{kg}-100 \mathrm{mg} /$ $\mathrm{kg}$ did not modulate the total inflammatory cells and eosinophils in BALf, while in lung tissues, TIO dosedependently reduced the airway inflammation along with the inflammation score. ${ }^{33}$ In BALB/c mice exposed to organic dust, intranasal TIO 2-200 ng decreased the overexpression of IL-4 and IL-6, with no effect on total and differential inflammatory cell counts, and levels of IL-13, 


\begin{tabular}{|c|c|c|c|c|c|c|c|c|c|c|c|}
\hline $\begin{array}{l}\text { GM- } \\
\text { CSF }\end{array}$ & $\begin{array}{l}\text { Proteolytic } \\
\text { Caspase } \\
\text { Activity }\end{array}$ & $\begin{array}{l}\text { Total } \\
\text { Inflammatory } \\
\text { Cells }\end{array}$ & Neutrophils & $\begin{array}{l}\text { Apoptotic } \\
\text { CD+T } \\
\text { Cells }\end{array}$ & LTB $_{4}$ & $\begin{array}{l}\text { MIP } \\
\alpha / \beta\end{array}$ & $\begin{array}{l}\text { MMP- } \\
\text { I }\end{array}$ & $\begin{array}{l}\text { MMP- } \\
2\end{array}$ & $\begin{array}{l}\text { MMP- } \\
9\end{array}$ & $\begin{array}{l}\text { TIMP- } \\
\text { I }\end{array}$ & $\begin{array}{l}\text { TIMP- } \\
2\end{array}$ \\
\hline I & 1 & I & I & I & 1 & I & I & I & I & 1 & 1 \\
\hline I & 1 & I & $\downarrow^{20}$ & 1 & 1 & 1 & 1 & 1 & 1 & 1 & 1 \\
\hline I & I & I & $\approx^{20}$ & I & I & I & 1 & 1 & 1 & 1 & 1 \\
\hline
\end{tabular}

TNF, MCP-1, and MIP-1 in BALf. TIO did not modulate the over-expression of IL-4, IL-6, IL-13, IL-17A, TNF- $\alpha$, MIP-1, and $\mathrm{KC}$ in lung tissue. ${ }^{34}$

In BALB/c mice challenged with OVA, nebulized TIO $36 \mu \mathrm{g}$ in $3 \mathrm{~mL}$ of sterile physiological saline induced a numerical decreasing trend in the total number of inflammatory cells in BALf, with no modulatory effect on macrophages, eosinophils, neutrophils, and lymphocytes. TIO reduced the pathological score of inflammatory cells infiltration in the airways and expression of programmed cell death 5 in lung tissue and BALf. ${ }^{35}$ TIO nebulized at $50 \mu \mathrm{g} / \mathrm{mL}$ in saline decreased the total inflammatory cell count, macrophages, and eosinophils, but not lymphocytes in BALf, and prevented the inflammatory reaction induced by the acute exposure to OVA in BALB/c mice. TIO also reduced the OVA-induced release of TGF- $\beta 1$, IL-4, IL-5, and IL-13 in BALf. ${ }^{22}$ Nebulized TIO $60 \mu \mathrm{g} / \mathrm{mL}$ administered to ICR mice challenged with OVA prevented the increased number of total leukocytes count in BALf and the infiltration of eosinophils in lung tissue and BALf, with no effect on the accumulation of macrophages and lymphocytes in BALf. TIO also decreased the gene overexpression of IL-5 and MMP-9 in lung tissue without affecting the activity of TIMP-1. In both BALf and lung tissue, TIO reduced the gene and protein over-expression of IL-4 and increased IFN- $\gamma$ level which was not modulated by OVA. ${ }^{36}$ In BALB/c mice exposed to ambient particulate matter and challenged with OVA, nebulized TIO $50 \mu \mathrm{g} / \mathrm{mL}$ reduced the increased total inflammatory cell, neutrophil, eosinophil, lymphocyte, and macrophage counts in BALf. TIO also inhibited the over-expression of IL-5, IL-6, IL-13, KC, but it did not modulate the release of IFN- $\gamma$ in BALf. ${ }^{37}$
In $\mathrm{BALB} / \mathrm{c}$ mice challenged with OVA, intranasal instillation of TIO $0.5 \mathrm{mg} / \mathrm{mL}$ reduced the airway eosinophilia and lymphocyte count, without modulating the macrophage and neutrophil counts in BALf. TIO reduced the inflammation score, eosinophilia and the number of infiltrating lymphocytes in lung parenchyma. $^{38}$ In advanced-age BALB/c mice challenged with OVA, intranasal administration of TIO $0.1 \mathrm{mM}$ in $50 \mu \mathrm{L}$ of phosphate-buffered saline (PBS) reduced the total inflammatory cell count, eosinophils, and neutrophils in BALf. TIO suppressed the pulmonary inflammation in lung tissue and the over-expression of IL-4, IL-5, and IL-13 in BALf, with no effect on the lymphocyte count. ${ }^{39}$

In a chronic model of asthma in BALB/c mice challenged with OVA for 3 months, intranasal administration of TIO $100 \mu \mathrm{M}$ in $50 \mu \mathrm{L}$ of PBS reduced the increased number of total inflammatory cells, macrophages, lymphocytes, eosinophils, but not the levels of neutrophils and IL5. TIO also induced a trend toward a decrease in the levels of IL-4 and IL-13. Paradoxically, in an acute model of asthma in BALB/c mice challenged with OVA for 4 days, intranasal administration of TIO further increased the number of total inflammatory cells, eosinophils, and macrophages, but not lymphocytes and neutrophils, and the over-expression of IL-4, IL-5, and IL-13 in BALf. ${ }^{40}$

In Hartley guinea pigs challenged with OVA, nebulized TIO $10-30 \mu \mathrm{M}$ reduced airway eosinophilia, with no effect on the levels of inflammatory cells number in BALf. ${ }^{41}$ In further studies, TIO did not prevent the increased levels of inflammatory cells in BALf following OVA challenge. ${ }^{42,43}$ However, the intratracheal administration of TIO $3 \mu \mathrm{g}$ reduced the extensive infiltration of leukocytes in BALf induced by OVA challenge. ${ }^{44}$ 
Table 2 Impact of Muscarinic Receptor Antagonists on Humoral Response Upon Induction of a Pro-Inflammatory Stimulus in Laboratory Animals. Statistically Significant Results with a $\mathrm{P}<0.05$ are Reported in the Table

\begin{tabular}{|c|c|c|c|c|c|c|c|c|c|}
\hline \multirow{2}{*}{$\begin{array}{l}\text { Investigated } \\
\text { Treatment and } \\
\text { ROA }\end{array}$} & \multirow{2}{*}{$\begin{array}{l}\text { Pro- } \\
\text { Inflammatory } \\
\text { Stimulus }\end{array}$} & \multicolumn{8}{|c|}{ Outcomes Investigated in the in vivo studies Carried Out on Laboratory Animals } \\
\hline & & IL-I $\beta$ & IL-4 & IL-5 & IL-6 & IL-8 & IL-13 & IL-I7A & IFN- $\gamma$ \\
\hline \multirow[t]{10}{*}{ TIO inh. } & OVA & I & $\begin{array}{l}\text { BALf: } \downarrow^{36,39} \\
\text { acute and } \\
\text { chronic } \\
\text { challenge; }{ }^{22} \\
\uparrow \text { acute } \\
\text { challenge; }{ }^{40} \approx \\
\text { chronic } \\
\text { challenge. } \\
\text { Lung: } \downarrow^{36}\end{array}$ & 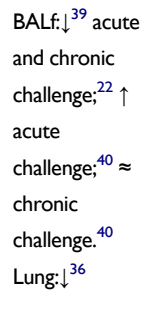 & 1 & I & $\begin{array}{l}\text { BALf: } \downarrow^{39} \text { acute } \\
\text { and chronic } \\
\text { challenge; } ;^{22} \uparrow \\
\text { acute } \\
\text { challenge; } ;^{40} \approx \\
\text { chronic } \\
\text { challenge }^{40}\end{array}$ & 1 & $\begin{array}{l}\text { BALf: } \uparrow^{36} \\
\text { Lung: } \uparrow^{36}\end{array}$ \\
\hline & $\begin{array}{l}\text { OVA + exposure } \\
\text { to } P M\end{array}$ & I & I & BALf: $\downarrow^{37}$ & BALf: $\downarrow^{37}$ & 1 & BALf: $\downarrow^{37}$ & I & BALf: $\approx^{37}$ \\
\hline & CS & $\begin{array}{l}\text { BALf: } \downarrow^{28,29} \\
\text { Lung: } \downarrow^{28,29}\end{array}$ & I & I & BALf: $\downarrow^{30,31}$ & BALf: $\downarrow^{31}$ & I & I & I \\
\hline & $\begin{array}{l}\mathrm{CS}+\mathrm{HINI} \\
\text { infection }\end{array}$ & Lung: $\approx^{27}$ & 1 & I & Lung: $\downarrow^{27}$ & 1 & I & 1 & Lung: $\downarrow^{27}$ \\
\hline & $\begin{array}{l}\text { CS + RSV } \\
\text { infection }\end{array}$ & Lung: $\approx^{27}$ & 1 & 1 & Lung: $\downarrow^{27}$ & I & 1 & 1 & Lung: $\downarrow^{27}$ \\
\hline & OD & 1 & $\begin{array}{l}\text { BALf: } \downarrow^{34 *} \cdot \\
\text { Lung: }: \approx^{34^{*}}\end{array}$ & I & $\begin{array}{l}\text { BALf: } \downarrow^{34^{*}} \cdot \\
\text { Lung: }: \approx^{34^{*}}\end{array}$ & 1 & $\begin{array}{l}\text { BALf: } \approx^{34 *} \text {. } \\
\text { Lung: } \approx^{34^{*}}\end{array}$ & Lung: $\approx^{34 *}$ & I \\
\hline & RB & $\begin{array}{l}\text { Lung: } \downarrow 40 \% \\
\text { IRB, } 50 \% \text { IRB, } \\
60 \% \text { ERB, and } \\
40 \% / 60 \% \\
\text { CRB }^{45}\end{array}$ & 1 & I & $\begin{array}{l}\text { Lung: } \downarrow 40 \% \\
\text { IRB, } 50 \% \text { IRB, } \\
60 \% E R B \text {, and } \\
40 \% / 60 \% \\
\text { CRB }^{45}\end{array}$ & I & I & I & I \\
\hline & $\mathrm{CdCl}_{2}$ & BALf: $\approx^{47}$ & I & 1 & I & 1 & I & I & I \\
\hline & LPS & I & I & 1 & BALf: $\downarrow^{30}$ & 1 & I & I & I \\
\hline & $\begin{array}{l}\text { Acidic solution } \\
\text { (with } \mathrm{HCl} \text { ) }\end{array}$ & 1 & 1 & 1 & I & BALf: $\downarrow^{46}$ & 1 & I & I \\
\hline \multirow[t]{2}{*}{$B C Q B$ inh. } & CS & $\begin{array}{l}\text { BALf: } \downarrow^{28} \\
\text { Lung: } \downarrow^{28}\end{array}$ & 1 & 1 & 1 & 1 & I & I & I \\
\hline & OVA & I & $\begin{array}{l}\text { BALf: } \downarrow^{36} \\
\text { Lung: } \downarrow^{36}\end{array}$ & Lung: $\downarrow^{36}$ & $\begin{array}{l}\text { NLF: } \downarrow^{50^{*}} \cdot \\
\text { Nasal } \\
\text { mucosa: } \downarrow^{49 *}\end{array}$ & I & $\begin{array}{l}\text { NLF: } \downarrow^{50^{*}} . \\
\text { Nasal } \\
\text { mucosa: } \downarrow^{50^{*}}\end{array}$ & I & $\begin{array}{l}\text { BALf: } \uparrow^{36} \\
\text { Lung: } \uparrow^{36}\end{array}$ \\
\hline GLY syst. & CS & 1 & 1 & I & I & 1 & 1 & I & I \\
\hline GLY inh. & CS & $\begin{array}{l}\text { BALf: } \downarrow^{29} \\
\text { Lung: } \downarrow^{29}\end{array}$ & 1 & I & I & 1 & 1 & I & I \\
\hline \multirow[t]{2}{*}{ IB inh. } & OVA & 1 & 1 & 1 & $\begin{array}{l}\text { NLF: } \downarrow^{50 *} \cdot \\
\text { Nasal } \\
\text { mucosa: } \downarrow^{50 *}\end{array}$ & 1 & $\begin{array}{l}\text { NLF: } \downarrow^{50^{*}} \cdot \\
\text { Nasal } \\
\text { mucosa: } \downarrow^{50^{*}}\end{array}$ & I & I \\
\hline & $\mathrm{CdCl}_{2}$ & 1 & 1 & I & I & I & I & I & I \\
\hline$A C L$ inh. & Af extract & 1 & BALf: $\approx^{48}$ & 1 & BALf: $\approx 48$ & 1 & BALf: $\approx^{48}$ & I & I \\
\hline
\end{tabular}




\begin{tabular}{|c|c|c|c|c|c|c|c|c|c|c|}
\hline $\begin{array}{l}\text { NF- } \\
\text { KB Activity }\end{array}$ & MCP-I & MIP-I & MIP-2 & KC & PDCD5 & TNF- $\alpha$ & MMP-2 & MMP-9 & TGF- $\beta$ I & TIMP-I \\
\hline I & 1 & I & 1 & 1 & $\begin{array}{l}\text { BALf: } \downarrow^{35} \\
\text { Lung: } \downarrow^{35}\end{array}$ & I & 1 & Lung: $\downarrow^{36}$ & $\begin{array}{l}\text { BALf: } \downarrow \text { chronic } \\
\text { challenge }\end{array}$ & Lung: $\approx 6$ \\
\hline I & 1 & I & 1 & BALf: $\downarrow^{37}$ & 1 & 1 & 1 & 1 & 1 & I \\
\hline I & $\begin{array}{l}\text { BALf: } \downarrow^{28-31} \\
\text { Lung: } \downarrow^{28,29}\end{array}$ & BALf: $\downarrow^{30}$ & BALf: $\downarrow^{30}$ & $\begin{array}{l}\text { BALf: } \downarrow^{28,30} \\
\text { Lung: } \downarrow^{28}\end{array}$ & 1 & $\begin{array}{l}\text { BALf: } \downarrow^{28-31} \\
\text { Lung: } \downarrow^{28,29}\end{array}$ & 1 & Lung: $\downarrow^{29}$ & $\begin{array}{l}\text { BALf: } \downarrow^{29} \\
\text { Lung: } \downarrow^{29}\end{array}$ & Lung: $\uparrow^{29}$ \\
\hline 1 & 1 & 1 & 1 & Lung: $\approx^{27}$ & 1 & Lung: $:^{27}$ & 1 & 1 & I & I \\
\hline I & 1 & 1 & 1 & Lung: $\approx^{27}$ & 1 & Lung: $\downarrow^{27}$ & 1 & 1 & 1 & I \\
\hline I & BALf: $: \approx^{34 *}$ & $\begin{array}{l}\text { BALf: } \approx^{34^{*}} . \\
\text { Lung: } \approx^{34^{*}}\end{array}$ & 1 & Lung: $: \approx^{34 *}$ & 1 & $\begin{array}{l}\text { BALf: } \approx \approx^{34 *} \\
\text { Lung: } \approx^{34^{*}}\end{array}$ & 1 & 1 & 1 & 1 \\
\hline I & 1 & 1 & 1 & 1 & 1 & 1 & 1 & 1 & 1 & 1 \\
\hline 1 & I & 1 & 1 & 1 & 1 & BALf: $\approx^{47}$ & BALf: $\downarrow^{47}$ & BALf: $\approx^{47}$ & 1 & I \\
\hline I & BALf: $: \approx^{30}$ & BALf: $: \approx^{30}$ & BALf: $\approx^{30}$ & 1 & 1 & BALf: $\approx^{30}$ & 1 & 1 & I & 1 \\
\hline I & 1 & 1 & 1 & 1 & 1 & 1 & 1 & 1 & 1 & I \\
\hline 1 & $\begin{array}{l}\text { BALf: } \downarrow^{28} \\
\text { Lung: } \downarrow^{28}\end{array}$ & 1 & 1 & $\begin{array}{l}\text { BALf: } \downarrow^{28} \\
\text { Lung: } \downarrow^{28}\end{array}$ & 1 & $\begin{array}{l}\text { BALf: } \downarrow^{28} \\
\text { Lung: } \downarrow^{28}\end{array}$ & 1 & 1 & 1 & I \\
\hline $\begin{array}{l}\text { Nasal } \\
\text { mucosa: } \downarrow^{50 *}\end{array}$ & 1 & 1 & 1 & 1 & 1 & $\begin{array}{l}\text { NLF: } \downarrow^{50^{*}} \cdot \text { Nasal } \\
\text { mucosa: } \downarrow^{50^{*}}\end{array}$ & 1 & Lung: $\downarrow^{36}$ & 1 & Lung: $\uparrow^{36}$ \\
\hline I & BALf: $\downarrow^{25}$ & 1 & BALf: $\downarrow^{25}$ & 1 & 1 & 1 & 1 & 1 & 1 & \\
\hline I & $\begin{array}{l}\text { BALf: } \downarrow^{29} \\
\text { Lung: } \downarrow^{29}\end{array}$ & 1 & 1 & 1 & I & $\begin{array}{l}\text { BALf: } \downarrow^{29} \\
\text { Lung: } \downarrow^{29}\end{array}$ & 1 & Lung: $\downarrow^{29}$ & $\begin{array}{l}\text { BALf: } \downarrow^{29} \\
\text { Lung: } \downarrow^{29}\end{array}$ & Lung: $\uparrow^{29}$ \\
\hline $\begin{array}{l}\text { Nasal } \\
\text { mucosa: } \downarrow^{50 *}\end{array}$ & I & 1 & 1 & 1 & 1 & $\begin{array}{l}\text { NLF: } \downarrow^{50 *} \cdot \text { Nasal } \\
\text { mucosa: } \downarrow^{50 *}\end{array}$ & 1 & 1 & 1 & I \\
\hline I & 1 & 1 & 1 & 1 & 1 & I & $\begin{array}{l}\text { BALf: } \approx^{51} \\
\text { chronic } \\
\text { challenge }^{52}\end{array}$ & $\begin{array}{l}\text { BALf: } \downarrow^{51} \approx \\
\text { chronic } \\
\text { challenge }^{52}\end{array}$ & I & I \\
\hline 1 & 1 & 1 & 1 & 1 & 1 & $\begin{array}{l}\text { BALf: } \approx \text { TNF }(\alpha \\
\text { and } \beta)^{48}\end{array}$ & 1 & 1 & 1 & 1 \\
\hline
\end{tabular}

(Continued) 
Table 2 (Continued).

\begin{tabular}{|c|c|c|c|c|c|c|c|c|c|}
\hline \multirow{2}{*}{$\begin{array}{l}\text { Investigated } \\
\text { Treatment and } \\
\text { ROA }\end{array}$} & \multirow{2}{*}{$\begin{array}{l}\text { Pro- } \\
\text { Inflammatory } \\
\text { Stimulus }\end{array}$} & \multicolumn{8}{|c|}{ Outcomes Investigated in the in vivo studies Carried Out on Laboratory Animals } \\
\hline & & IL-1B & IL-4 & IL-5 & IL-6 & IL-8 & IL-13 & IL-I7A & IFN- $\gamma$ \\
\hline \multirow[t]{2}{*}{ 4-DAMP syst. } & CS & I & 1 & 1 & I & I & I & 1 & 1 \\
\hline & LPS & I & I & 1 & Lung: $\downarrow^{26}$ & I & I & l & I \\
\hline \multirow{2}{*}{$\begin{array}{l}\text { Mepenzolate bromide } \\
\text { inh. }\end{array}$} & PPE & I & I & 1 & I & 1 & 1 & I & I \\
\hline & CS & I & I & I & I & l & 1 & I & I \\
\hline Anisodamine syst. & OVA & I & BALf: $\downarrow^{55}$ & I & I & I & 1 & 1 & BALf: $\uparrow^{55}$ \\
\hline
\end{tabular}

Note: *Intranasal or intratracheal instillation.

Abbreviations: ACL, aclidinium; Af, Aspergillus fumigatus; $\mathrm{BALf}$, bronchoalveolar lavage fluid; $\mathrm{BCQB}$, bencycloquidium bromide; $\mathrm{CdCl}{ }_{2}$, cadmium chloride; $\mathrm{COPD}$, chronic obstructive pulmonary disease; CS, cigarette smoke; GLY, glycopyrronium; HINI, influenza virus A/PR/8/34; IB, ipratropium bromide; IFN, interferon; IL, interleukin; KC, keratinocyte-derived chemokine; LPS, lipopolysaccharide; MAC-I, macrophage-I antigen; MCP, monocyte chemoattractant protein; MIP, macrophage inflammatory protein; MMP, matrix metalloproteinase; NA, not available; NLF, nasal lavage fluid; OVA, ovalbumin; PDCD5, programmed cell death protein 5; PM, particulate matter; ROA, route of administration; RSV, respiratory syncytial virus; TGF- $\beta$ I, tumor growth factor-beta I; TIMP, tissue inhibitor of metalloproteinase; TIO, tiotropium bromide or tiotropium bromide hydrate; TNF- $\alpha$, tumor necrosis factor-alpha; 4-DAMP, I, I-dimethyl-4-diphenylacetoxypiperidinium iodide.

In an in vivo model of acute resistive breathing (RB) in healthy rats, inhaled TIO $1 \mathrm{mg} / \mathrm{mL}$ prevented the overexpression of IL-1 $\beta$ and IL- 6 in lung tissue and reduced the total inflammatory cell, macrophage, and neutrophil counts and the total protein in BALf. ${ }^{45}$

In $\mathrm{BALB} / \mathrm{c}$ mice exposed to intra-oesophageal hydrochloric acid $(\mathrm{HCl})$ instillation, inhalation of TIO 5$25 \mu \mathrm{g} / \mathrm{mL}$ reduced the inflammatory cells infiltration in lung tissue and the total inflammatory cell count, macrophages, lymphocytes, and neutrophils in BALf. TIO also reduced IL-8 over-expression in BALf. ${ }^{46}$ In SpragueDawley rats exposed to cadmium chloride $\left(\mathrm{CdCl}_{2}\right)$, nebulized TIO $70-350 \mu \mathrm{g} / 15 \mathrm{~mL}$ reduced the number of total inflammatory cells, neutrophils, and protein concentration in BALf, with no effect on the macrophage count. TIO decreased the over-expression of IL-1 $\beta$, reduced the increased MMP-2 activity in BALf, with no effect on TNF- $\alpha$ and MMP-9. TIO also suppressed the $\mathrm{CdCl}_{2}-$ induced infiltration of neutrophils and macrophages in the alveoli, peri-bronchial regions and parenchyma, thus reducing the inflammatory scores associated with the severity and extent of histological injuries. ${ }^{47}$

\section{Aclidinium}

In $\mathrm{BALB} / \mathrm{c}$ mice challenged with Aspergillus fumigatus extract, aerosolized ACL $1 \mathrm{mg} / \mathrm{mL}$ reduced the total protein count and airway eosinophilia in BALf. ACL did not modulate the number of macrophages, neutrophils, and lymphocytes, as well as the over-expression of IL-4, IL6, IL-13, and TNF in BALf. ${ }^{48}$
In Hartley guinea pigs exposed to CS, treatment with nebulized ACL $30 \mu \mathrm{g} / \mathrm{mL}$ attenuated the CS-induced infiltration of neutrophils in the alveolar septa, with no difference detected in the number of macrophages or eosinophils. $^{49}$

\section{Glycopyrronium Bromide}

In $\mathrm{C} 57 \mathrm{BL} / 6 \mathrm{~J}$ mice subchronically exposed to $\mathrm{CS}$, intraperitoneal injection of GLY $3 \mathrm{mg} / \mathrm{kg}$ reduced the lung inflammatory score, total protein concentration, total inflammatory cell count, macrophages, lymphocytes, neutrophils, and the over-expression of MCP-1 and MIP-2 in BALf. ${ }^{25}$

In ICR mice exposed to CS, pretreatment with aerosolized GLY $150-600 \mu \mathrm{g} / \mathrm{mL}$ reduced the number of total inflammatory cells, neutrophils, macrophages, but not lymphocytes, and decreased the gene and protein overexpression of IL- $1 \beta$, TNF- $\alpha$, MCP-1, and TGF- $\beta 1$ in BALf and lung tissue. GLY also reduced the infiltration of neutrophils and macrophages in the alveolar spaces and improved the CS-upregulated activity of MMP-9 and TIMP-1 in lung tissue. ${ }^{29}$

\section{Ipratropium Bromide}

In Sprague-Dawley rats challenged with OVA, intranasal instillation of IB $3 \mathrm{mg} / \mathrm{kg}$ suppressed the infiltration of eosinophils in the nasal mucosa, reduced the gene and protein over-expression of IL-6, IL-13, and TNF- $\alpha$ in NLF and nasal mucosa, and inhibited the nuclear translocation of NF- $\kappa$ B p65 and p50 subunits in nasal mucosa. ${ }^{50}$

In Sprague-Dawley rats exposed to $\mathrm{CdCl}_{2}$, pretreatment with nebulized IB $0.04-0.20 \mathrm{mg} / 20 \mathrm{~mL}$ reduced the number 


\begin{tabular}{|c|c|c|c|c|c|c|c|c|c|c|}
\hline $\begin{array}{l}\text { NF- } \\
\text { KB Activity }\end{array}$ & MCP-I & MIP-I & MIP-2 & KC & PDCD5 & TNF- $\alpha$ & MMP-2 & MMP-9 & TGF- $\beta$ I & TIMP-I \\
\hline I & 1 & 1 & 1 & BALf: $\downarrow^{53}$ & 1 & 1 & 1 & 1 & 1 & 1 \\
\hline Lung: $\downarrow^{26}$ & 1 & 1 & 1 & 1 & 1 & Lung: $\downarrow^{26}$ & 1 & 1 & 1 & 1 \\
\hline I & BALf: $\downarrow^{54}$ & 1 & BALf: $\approx^{54}$ & BALf: $\downarrow^{54}$ & 1 & BALf: $\downarrow^{54}$ & 1 & 1 & 1 & 1 \\
\hline 1 & $\begin{array}{l}\text { BALf: } \downarrow^{54 *} . \\
\text { Lung: } \approx^{54 *}\end{array}$ & 1 & $\begin{array}{l}\text { BALff: } \downarrow^{54 *} . \\
\text { Lung: } \downarrow^{54 *}\end{array}$ & $\begin{array}{l}\text { BALf: } \downarrow^{54 *} \cdot \\
\text { Lung: } \downarrow^{54 *}\end{array}$ & 1 & $\begin{array}{l}\text { BALf: } \downarrow^{54 *} . \\
\text { Lung: } \approx^{54 *}\end{array}$ & I & I & 1 & 1 \\
\hline I & 1 & 1 & 1 & 1 & 1 & 1 & 1 & 1 & 1 & 1 \\
\hline
\end{tabular}

of neutrophils and the activity of MMP-9 in BALf, with no modulatory action on macrophages, total inflammatory cell count, and MMP-2. IB suppressed the extent of lung injuries and reduced the severity of inflammatory cell infiltration in lung tissue, leading to improvement in lung inflammation score. $^{51}$ In Sprague-Dawley rats chronically exposed to $\mathrm{CdCl}_{2}$, pretreatment with nebulized IB $0.20 \mathrm{mg} / 20 \mathrm{~mL}$ did not exert a modulatory effect on the increased protein concentration, MMP-2 and MMP-9 activity, and on the number of total inflammatory cells, neutrophils, macrophages in BALf. Conversely, single and repeat inhalation of IB followed by an acute exposure to $\mathrm{CdCl}_{2}$ reduced the total inflammatory cell count and the neutrophil count, with no modulatory effect on macrophages. ${ }^{52}$

\section{Bencycloquidium Bromide}

In ICR mice exposed to $\mathrm{CS}$, aerosol pre-treatment with bencycloquidium bromide (BCQB) 75-300 $\mu \mathrm{g} / \mathrm{mL}$ reduced the accumulation of total inflammatory cells and neutrophils in BALf, and the score of inflammatory cell infiltration in lung tissues. BCQB also inhibited the gene and protein overexpression of $\mathrm{KC} / \mathrm{CXCL} 1$ and $\mathrm{MCP}-1$ in BALf and lung tissues, and TNF- $\alpha$ gene over-expression in lung tissues. BCQB reduced the macrophage count and TNF- $\alpha$ release in BALf, and the gene and protein over-expression of IL-1 $\beta$ in BALf and lung tissues, but no change in lymphocyte accumulation was observed in BALf. ${ }^{28}$

In Sprague-Dawley rats challenged with OVA, intranasal instillation of BCQB $0.75-3 \mathrm{mg} / \mathrm{kg}$ inhibited the aggregation of mast cells and the nuclear translocation of
NF- $\kappa \mathrm{B}$ p65 and p50 subunits in nasal mucosa. BCQB reduced the over-expression of IL-6, IL-13, and TNF- $\alpha$ in nasal lavage fluid (NLF) and nasal mucosa, along with the infiltration of eosinophils in nasal mucosa. BCQB also reduced the over-expression of IL-13 in NLF but had no modulatory effect on IL- 6 , TNF- $\alpha$, and the eosinophils present in the nasal mucosa. ${ }^{50}$

In ICR mice challenged with OVA, nebulized BCQB $60-240 \mu \mathrm{g} / \mathrm{mL}$ reduced the total number of leukocytes and eosinophils, but not lymphocytes in BALf. BCQB decreased the gene over-expression of IL-5 and MMP-9 and increased the gene expression of TIMP-1 in lung tissue, whereas in both BALf and lung tissue it reduced the gene and protein expression of IL-4 and increased IFN- $\gamma$. BCQB attenuated eosinophil infiltration in lung tissue and inhibited the accumulation of macrophages in BALf. $^{36}$

\section{I, I-Dimethyl-4-Diphenylacetoxypiperidinium lodide}

In $\mathrm{C} 57 \mathrm{Bl} / 6 \mathrm{NTac}$ wild-type mice exposed to $\mathrm{CS}$, intraperitoneal administration of 4-DAMP $1 \mathrm{mg} / \mathrm{kg}$ reduced the number of total inflammatory cells, macrophages, lymphocytes, neutrophils, and the release of $\mathrm{KC}$ in the BALf. $^{53}$ In Kunming mice challenged with LPS, intraperitoneal administration of 4-DAMP $1 \mathrm{mg} / \mathrm{kg}$ reduced the BALf number of total inflammatory cells and the percentage of neutrophils, and in lung tissue, it reduced the level of IL- 6 and the degradation of IKB- $\alpha$ promoted by LPS stimulation. 4-DAMP also reduced the concentration of TNF- $\alpha$ in lung tissue. ${ }^{26}$ 
Table 3 Impact of Muscarinic Receptor Antagonists on the Inflammatory Cellular Response Induced by Different Pro-Inflammatory Stimuli in Laboratory Animals. Statistically Significant Results with a $\mathrm{P}<0.05$ are Reported in the Table

\begin{tabular}{|c|c|c|c|c|}
\hline \multirow{2}{*}{$\begin{array}{l}\text { Investigated } \\
\text { Treatment }\end{array}$} & \multirow{2}{*}{$\begin{array}{l}\text { Pro-Inflammatory } \\
\text { Stimulus }\end{array}$} & \multicolumn{3}{|c|}{ Investigated Outcomes in the in vivo Studies on Laboratory Animals } \\
\hline & & $\begin{array}{l}\text { Total Inflammatory Cell } \\
\text { Count }\end{array}$ & Eosinophils & Macrophages \\
\hline \multirow[t]{11}{*}{ TIO inh. } & OVA & $\begin{array}{l}\text { BALf: } \downarrow^{36,44 *} \text { in advanced-age } \\
\text { mice, }{ }^{39} \text { chronic challenge, }{ }^{40} \\
\text { acute and chronic challenge; }{ }^{22} \\
\uparrow \text { acute challenge; }{ }^{40} \approx^{35,41,42}\end{array}$ & $\begin{array}{l}\text { BALf: } \downarrow \text { in advanced-age mice, }{ }^{39} \\
\text { acute onset and relapse of allergic } \\
\text { asthma, }{ }^{36,38^{*}} \text { acute challenge, }{ }^{22} \\
\text { chronic challenge; }{ }^{22,40} \uparrow \text { acute } \\
\text { challenge; }{ }^{40} \approx{ }^{35,41-43^{*}} . \\
\text { Lung: } \downarrow \text { in submucosal } \\
\text { cartilaginous airways, }{ }^{41} \text { acute } \\
\text { onset and relapse of allergic } \\
\text { asthma; }{ }^{36,38^{*}} \approx \text { in submucosal and } \\
\text { adventitia of non-cartilaginous } \\
\text { airways and adventitia of } \\
\text { cartilaginous airways, }{ }^{41} \text { total and } \\
\text { nerve-associated eosinophils }{ }^{43^{*}}\end{array}$ & $\begin{array}{l}\text { BALf: } \uparrow \text { acute challenge; }{ }^{40} \\
\downarrow \text { acute challenge, }{ }^{22} \text { chronic } \\
\text { challenge; }{ }^{22,40} \approx^{35,36,41-43^{*}}, \\
\text { acute onset of allergic asthma }{ }^{38^{*}}\end{array}$ \\
\hline & $\begin{array}{l}\text { OVA + exposure to } \\
\text { PM }\end{array}$ & BALf: $\downarrow^{37}$ & BALf: $\downarrow^{37}$ & BALf: $\downarrow^{37}$ \\
\hline & CS & $\begin{array}{l}\text { BALf: } \downarrow^{28-31} \\
\text { Lung: } \downarrow^{28,31} \text { Serum: } \approx^{31}\end{array}$ & $\begin{array}{l}\text { BALf: } \downarrow^{31} \\
\text { Serum: }: \approx^{31}\end{array}$ & BALf: $\downarrow^{28,31} \approx 29$ \\
\hline & $\mathrm{CS}+\mathrm{HINI}$ infection & BALf: $\downarrow^{27}$ & I & BALf: $\downarrow^{27}$ \\
\hline & CS + RSV infection & I & I & BALf: $\approx 27$ \\
\hline & OD & BALf: $\approx^{3 * *}$ & BALf: $\approx^{3 *}$ & BALf: $\approx^{3 * *}$ \\
\hline & $\begin{array}{l}\text { House dust mite } \\
\text { extract }\end{array}$ & BALf: $\approx^{33 *}$ & BALf: $\approx^{33^{*}}$ & I \\
\hline & RB & $\begin{array}{l}\text { BALf: } \downarrow 40 \% \text { IRB, } 60 \% \text { ERB, and } \\
40 \% / 60 \% \mathrm{CRB}^{45} \approx 50 \% \mathrm{IRB}^{45}\end{array}$ & l & 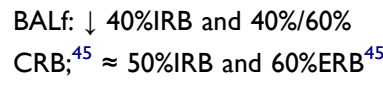 \\
\hline & $\mathrm{CdCl}_{2}$ & BALf: $\downarrow^{47}$ & I & $\begin{array}{l}\text { BALf: } \approx^{47} \\
\text { Lung: } \downarrow \text { in alveoli, peri-bronchial } \\
\text { regions, and parenchyma. }{ }^{47}\end{array}$ \\
\hline & LPS & BALf: $\approx^{30}$ & I & I \\
\hline & Acidic solution & $\begin{array}{l}\text { BALf: } \downarrow^{46} \\
\text { Lung: } \downarrow^{46}\end{array}$ & I & BALf: $\downarrow^{46}$ \\
\hline \multirow[t]{2}{*}{$B C Q B$ inh. } & CS & $\begin{array}{l}\text { BALf: } \downarrow^{28} \\
\text { Lung: } \downarrow^{28}\end{array}$ & 1 & BALf: $\downarrow^{28}$ \\
\hline & OVA & BALf: $\downarrow^{36}$ & $\begin{array}{l}\text { BALf: } \downarrow^{36} \\
\text { Lung: } \downarrow^{36} \\
\text { Nasal mucosa: } \downarrow^{50^{*}}\end{array}$ & BALf: $\downarrow^{36}$ \\
\hline
\end{tabular}




\begin{tabular}{|c|c|c|c|c|c|}
\hline Neutrophils & Lymphocytes & Monocytes & Basophils & $\begin{array}{l}\text { Total Protein } \\
\text { Amount }\end{array}$ & $\begin{array}{l}\text { Lung } \\
\text { Inflammatory } \\
\text { Score }\end{array}$ \\
\hline $\begin{array}{l}\text { BALf: } \downarrow \text { in advanced-age mice; }{ }^{39} \approx^{35,41-43^{*}}, \\
\text { acute challenge, }{ }^{40} \text { chronic challenge, }{ }^{40} \\
\text { acute onset of allergic asthma }{ }^{38^{*}}\end{array}$ & $\begin{array}{l}\text { BALf: } \downarrow \text { chronic challenge, }{ }^{22,40} \\
\text { acute onset and relapse of } \\
\text { allergic asthma }{ }^{38^{*}} ; \approx^{35,36,39,41,43^{*}} \text {, } \\
\text { acute challenge }{ }^{22,40}\end{array}$ & I & I & I & $\begin{array}{l}\text { Lung: } \downarrow \text { acute } \\
\text { onset and } \\
\text { relapse of } \\
\text { allergic } \\
\text { asthma }\end{array}$ \\
\hline BALf: $\downarrow^{37}$ & BALf: $\downarrow^{37}$ & I & I & I & I \\
\hline $\begin{array}{l}\text { BALf: } \downarrow^{28-30} \approx^{31} \\
\text { Serum: } \approx^{31}\end{array}$ & $\begin{array}{l}\text { BALf: } \downarrow^{28,29} \approx^{31} \\
\text { Serum: } \approx^{31}\end{array}$ & $\begin{array}{l}\text { BALf: }: 30 \\
\text { Serum: }: \approx^{31}\end{array}$ & Serum: $\approx^{31}$ & Serum: $\approx^{31}$ & Lung: $\downarrow^{28,31}$ \\
\hline BALf: $\downarrow^{27}$ & I & I & I & I & I \\
\hline BALf: $\downarrow^{27}$ & I & l & I & I & l \\
\hline BALf: $\approx^{34 *}$ & BALf: $\approx^{34 *}$ & l & l & I & I \\
\hline I & I & I & I & I & Lung: $\downarrow^{33^{*}}$ \\
\hline $\begin{array}{l}\text { BALf: } \downarrow 40 \% \text { IRB } 50 \% \text { IRB, } 60 \% \text { ERB, and } \\
40 \% / 60 \% \mathrm{CRB}^{45}\end{array}$ & I & I & I & $\begin{array}{l}\text { BALf: } \downarrow 40 \% \text { IRB } \\
\text { and } 40 \% / 60 \% \\
\text { CRB; }^{45} \approx 50 \% \text { IRB } \\
\text { and } 60 \% \text { ERB }^{45}\end{array}$ & I \\
\hline $\begin{array}{l}\text { BALf: } \downarrow^{47} \\
\text { Lung: } \downarrow \text { in alveoli, peri-bronchial regions, } \\
\text { and parenchyma }{ }^{47}\end{array}$ & I & I & I & BALf: $\downarrow^{47}$ & Lung: $\downarrow^{47}$ \\
\hline $\begin{array}{l}\text { BALf: } \downarrow^{30} \\
\text { Lung: } \downarrow \text { in cartilaginous, non-cartilaginous } \\
\text { airways and parenchyma }{ }^{32}\end{array}$ & I & BALf: $\approx^{30}$ & I & I & I \\
\hline BALf: $\downarrow^{46}$ & BALf: $\downarrow^{46}$ & I & I & I & I \\
\hline $\begin{array}{l}\text { BALf: } \downarrow^{28} \\
\text { Lung: } \downarrow^{28}\end{array}$ & BALf: $\approx^{28}$ & I & I & I & Lung: $\downarrow^{28}$ \\
\hline 1 & BALf: $\approx^{36}$ & I & I & I & I \\
\hline
\end{tabular}

(Continued) 
Table 3 (Continued).

\begin{tabular}{|c|c|c|c|c|}
\hline \multirow{2}{*}{$\begin{array}{l}\text { Investigated } \\
\text { Treatment }\end{array}$} & \multirow{2}{*}{$\begin{array}{l}\text { Pro-Inflammatory } \\
\text { Stimulus }\end{array}$} & \multicolumn{3}{|c|}{ Investigated Outcomes in the in vivo Studies on Laboratory Animals } \\
\hline & & $\begin{array}{l}\text { Total Inflammatory Cell } \\
\text { Count }\end{array}$ & Eosinophils & Macrophages \\
\hline GLY syst. & CS & BALf: $\downarrow^{25}$ & l & BALf: $\downarrow^{25}$ \\
\hline GLY inh. & CS & BALf: $\downarrow^{29}$ & I & $\begin{array}{l}\text { BALf: } \downarrow^{29} \\
\text { Lung: } \downarrow \text { in alveolar spaces }{ }^{29}\end{array}$ \\
\hline V0162 inh. & OVA & BALf: $\downarrow^{44^{*}}$ & I & I \\
\hline \multirow[t]{2}{*}{ IB inh. } & OVA & l & Nasal mucosa: $\downarrow^{50^{*}}$ & l \\
\hline & $\mathrm{CdCl}_{2}$ & $\begin{array}{l}\text { BALf: } \downarrow \text { acute challenge; }{ }^{52} \approx^{51} \\
\text { chronic challenge }\end{array}$ & I & $\begin{array}{l}\text { BALf: } \approx^{51} \text { acute and chronic } \\
\text { challenge }{ }^{52}\end{array}$ \\
\hline \multirow[t]{2}{*}{$A C L$ inh. } & CS & l & $\begin{array}{l}\text { Lung: } \approx \text { in alveolar septa and } \\
\text { airways } 49\end{array}$ & $\begin{array}{l}\text { Lung: } \approx \text { in alveolar septa and } \\
\text { airways } 49\end{array}$ \\
\hline & Af extract & I & BALf: $\downarrow^{48}$ & BALf: $\approx 48$ \\
\hline \multirow[t]{2}{*}{ 4-DAMP syst. } & $\mathrm{CS}$ & BALf: $\downarrow^{53}$ & 1 & BALf: $\downarrow^{53}$ \\
\hline & LPS & BALf: $\downarrow^{26}$ & 1 & I \\
\hline 4-DAMP inh. & PPE & BALf: $\approx^{5 *}$ & I & I \\
\hline \multirow{2}{*}{$\begin{array}{l}\text { Mepenzolate } \\
\text { bromide inh. }\end{array}$} & PPE & BALf: $\downarrow^{54}$ & 1 & I \\
\hline & CS & Lung: $\downarrow^{54^{*}}$ & 1 & Lung: $\downarrow$ in alveoli ${ }^{5 *}$ \\
\hline $\begin{array}{l}\text { Anisodamine } \\
\text { syst. }\end{array}$ & OVA & $\begin{array}{l}\text { BALf: } \downarrow^{55} \\
\text { Lung: } \downarrow \text { in peribronchial and } \\
\text { perivascular regions }{ }^{54}\end{array}$ & $\begin{array}{l}\text { BALf: } \downarrow^{55} \\
\text { Lung: } \downarrow \text { in airway walls }{ }^{55}\end{array}$ & I \\
\hline
\end{tabular}

Note: *Intranasal or intratracheal instillation.

Abbreviations: $\mathrm{ACL}$, aclidinium; Af, Aspergillus fumigatus; $\mathrm{BALf}$, bronchoalveolar lavage fluid; $\mathrm{BCQB}$, bencycloquidium bromide; $\mathrm{CdCl}{ }_{2}$, cadmium chloride; $\mathrm{COPD}$ chronic obstructive pulmonary disease; CRB, combined resistive breathing; CS, cigarette smoke; ERB, expiratory resistive breathing; GLY, glycopyrronium; HINI, influenza virus A/PR/8/34; IB, ipratropium bromide; IFN, interferon; IL, interleukin; IRB, inspiratory resistive breathing; KC, keratinocyte-derived chemokine; LPS, lipopolysaccharide; MAC-I, macrophage-I antigen; MCP, monocyte chemoattractant protein; MIP, macrophage inflammatory protein; MMP, matrix metalloproteinase; NA, not available; NLF, nasal lavage fluid; OVA, ovalbumin; PDCD5, programmed cell death protein 5; PM, particulate matter; RB, resistive breathing; ROA, route of administration; RSV, respiratory syncytial virus; TGF- $\beta$ I, tumor growth factor-beta I; TIMP, tissue inhibitor of metalloproteinase; TIO, tiotropium bromide or tiotropium bromide hydrate; TNF- $\alpha$, tumor necrosis factor-alpha; 4-DAMP, I, I-dimethyl-4-diphenylacetoxypiperidinium iodide.

Single intratracheal administration of 4-DAMP $3.8-$ $38.0 \mu \mathrm{g} / \mathrm{kg}$ to ICR mice stimulated with porcine pancreatic elastase (PPE), had no modulatory effect on the number of total inflammatory cells and neutrophil count in BALf. ${ }^{54}$

\section{Mepenzolate}

In $\mathrm{DBA} / 2$ and ICR mice exposed to $\mathrm{CS}$, intratracheal administration of mepenzolate $38.0 \mu \mathrm{g} / \mathrm{kg}$ reduced the total number of inflammatory cells, neutrophils, and alveolar macrophages in lung tissue, and decreased the gene over-expression of MIP-2 and KC, but not MCP-1 and TNF- $\alpha$. Mepenzolate reduced the protein overexpression of MIP-2, KC, MCP-1, and TNF- $\alpha$ in BALf. $^{54}$

In ICR mice challenged with PPE, inhaled mepenzolate $0.38-38.0 \mu \mathrm{g} / \mathrm{kg}$ reduced the total number of leukocytes and neutrophils, and the over-expression of TNF- $\alpha$, MCP-1, and KC, but not MIP-2 in the BALf. Mepenzolate partially restored the gene and protein 


\begin{tabular}{|c|c|c|c|c|c|}
\hline Neutrophils & Lymphocytes & Monocytes & Basophils & $\begin{array}{l}\text { Total Protein } \\
\text { Amount }\end{array}$ & $\begin{array}{l}\text { Lung } \\
\text { Inflammatory } \\
\text { Score }\end{array}$ \\
\hline BALf: $\downarrow^{25}$ & BALf: $\downarrow^{25}$ & l & I & BALf: $\downarrow^{25}$ & Lung: $\downarrow^{25}$ \\
\hline $\begin{array}{l}\text { BALf: } \downarrow^{29} \\
\text { Lung: } \downarrow \text { in alveolar spaces }{ }^{29}\end{array}$ & BALf: $\approx 29$ & l & l & l & I \\
\hline I & l & l & l & l & I \\
\hline I & l & l & l & l & I \\
\hline $\begin{array}{l}\text { BALf: } \downarrow^{51} \text { acute challenge; }{ }^{52} \approx \text { chronic } \\
\text { challenge }\end{array}$ & l & l & I & $\begin{array}{l}\text { BALf: } \approx \text { chronic } \\
\text { challenge }^{52}\end{array}$ & Lung: $\downarrow^{51}$ \\
\hline Lung: $\downarrow$ in alveolar septa ${ }^{49}$ & l & l & l & l & I \\
\hline BALf: $\approx^{48}$ & BALf: $\approx 48$ & l & l & BALf: $\downarrow^{48}$ & I \\
\hline BALf: $\downarrow^{53}$ & BALf: $\downarrow^{53}$ & l & l & l & l \\
\hline BALf: $\downarrow^{26}$ & l & l & l & l & I \\
\hline BALf: $\approx^{5 *}$ & l & l & l & l & I \\
\hline BALf: $\downarrow^{54}$ & I & l & I & l & I \\
\hline Lung: $\downarrow^{54 *}$ & l & l & l & l & l \\
\hline I & I & l & l & l & l \\
\hline
\end{tabular}

over-expression of HDAC2, as well as HDAC enzymatic activity, and suppressed the level of phosphorylated NF- $\mathrm{NB}$, without exerting a modulatory effect on $\mathrm{I} \kappa \mathrm{B}-\alpha .^{54}$

\section{Anisodamine}

In $\mathrm{BALB} / \mathrm{c}$ mice challenged with OVA, intraperitoneal administration of anisodamine $0.75-3 \quad \mathrm{mg} / \mathrm{kg}$ inhibited the influx of total inflammatory cells and eosinophils in BALf. Anisodamine suppressed the peribronchial and perivascular infiltration of inflammatory cells in the lungs, reduced the influx of eosinophils into airway walls and the over-expression of IL-4 $(-83.00 \%)$, and increased the level of IFN- $\gamma$ in BALf. ${ }^{55}$

\section{V0162}

In guinea pigs challenged with OVA, intratracheal administration of V0162 $50 \mu \mathrm{g}$ reduced the extensive infiltration of leukocytes in BALf $(-27.00 \%){ }^{44}$ 


\section{Anti-Inflammatory Effect of Muscarinic} Receptor Antagonists in Clinical Studies

An overview concerning the anti-inflammatory impact of TIO administered via inhalation in COPD patients is reported in Table 4.

Four weeks of treatment with TIO $18 \mu \mathrm{g}$ reduced the synthesis of $\mathrm{LTB}_{4}$ by blood neutrophils activated with formyl-L-methionyl-L-leucyl-phenylalanine and primed with GM-CSF, ${ }^{56}$ with no reduction in the release of IL-6 and TNF- $\alpha$ in the exhaled breath condensate of stable COPD patients. ${ }^{57}$

A 3-month treatment with TIO $18 \mu \mathrm{g}$ increased the expression of acetylated histone $\mathrm{H} 3$ and the release of IL-8 and MMP-9 in induced sputum of COPD patients. $^{58,59}$ No modulatory effect was detected on HDAC2 expression, ${ }^{58}$ serum level of C-reactive protein (CRP), and total number of inflammatory cells, macrophages, neutrophils, and eosinophils. ${ }^{59}$

A 6-month treatment with TIO $18 \mu \mathrm{g}$ reduced the number of white blood cells but did not modulate the serum levels of CRP, IL-8, serum amyloid A, TNF- $\alpha$, and fibrinogen. ${ }^{60}$

Treatment for 1 year with TIO $18 \mu \mathrm{g}$ increased the concentration of IL- 8 in the sputum of smoking COPD patients, without affecting the levels of serum CRP, serum IL-6, and sputum IL-6. ${ }^{61}$

\section{Quality of Evidence and Risk of Bias}

Three out of six clinical studies $(50.00 \%)$ included in this systematic review were ranked as being of medium quality (Jadad score $=3$ ), whereas the other half $(50.00 \%)$ of them was characterized by low-quality level (Jadad score $<3$ ).

The traffic light plot for the assessment of the risk of bias of each included clinical study is reported in Figure $1 \mathrm{~A}$, and the weighted plot for the assessment of the overall risk of bias by domains is shown in Figure 1B.

Most of the clinical studies had a low risk of bias for the randomization process (3 [50.00\%]), missing outcome data $(5[83.33 \%])$, and selection of the reported results $(6$ [100.00\%]). Of the six clinical trials, three $(50.00 \%)$ had a high risk of bias due to deviations from intended intervention whereas four studies (66.67\%) had some concerns on the risk of bias in the domain of measurement of the outcomes.

\section{Discussion}

The evidence originating from the present systematic review indicates that therapy with muscarinic receptor

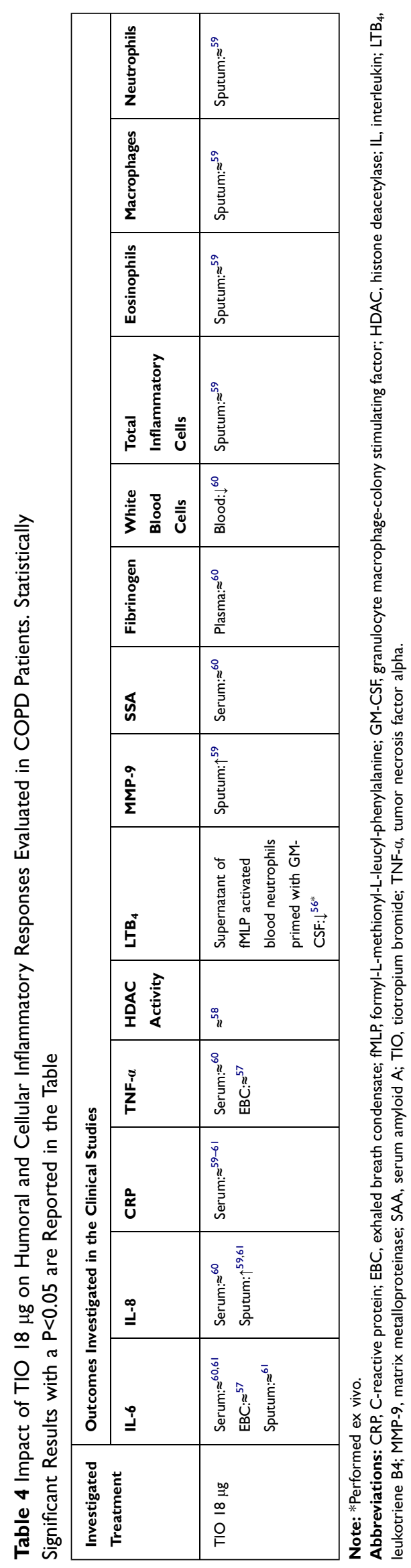




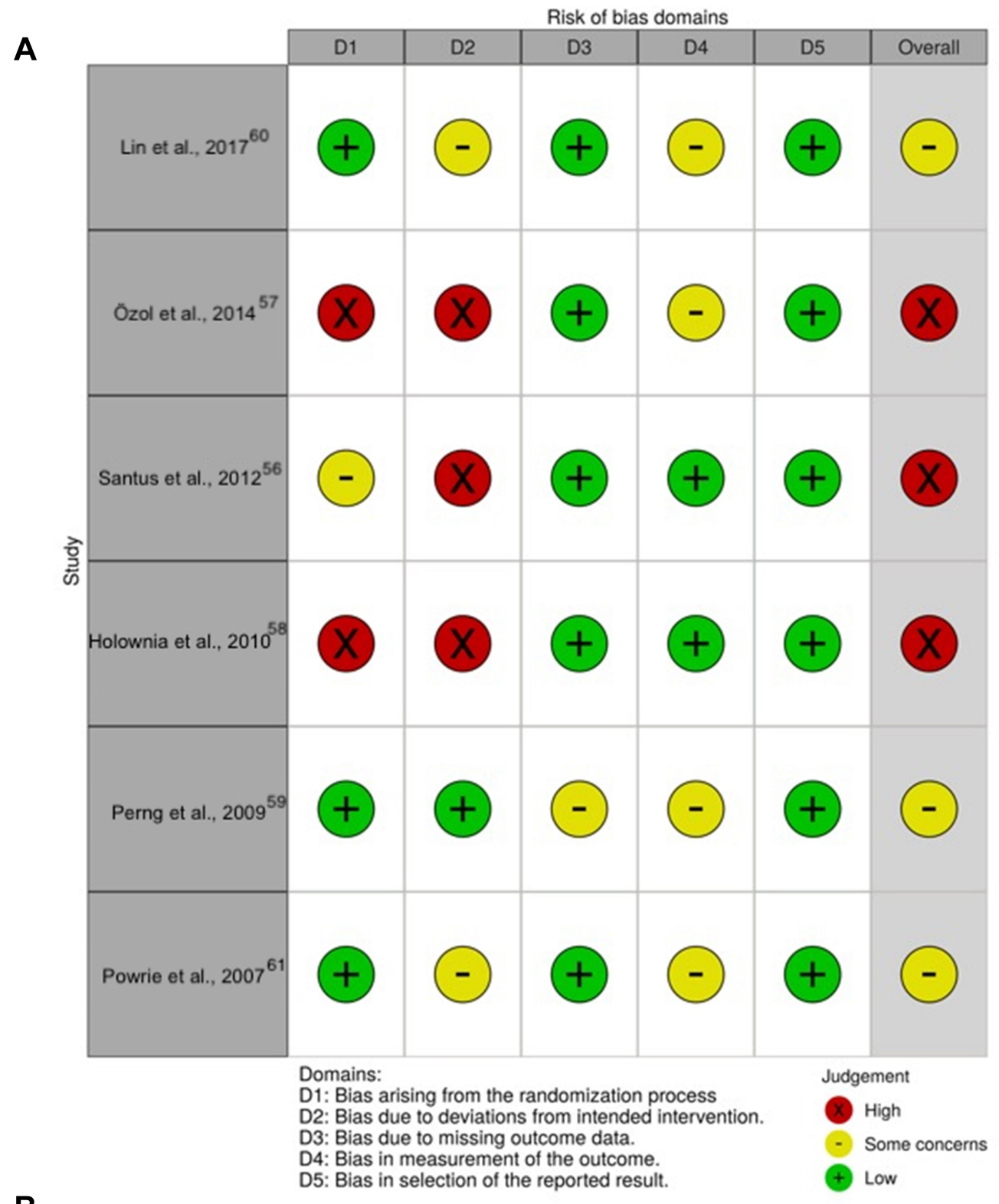

B

Bias arising from the randomization process Bias due to deviations from intended interventions Bias due to missing outcome data Bias in measurement of the outcome Bias in selection of the reported result Overall risk of bias

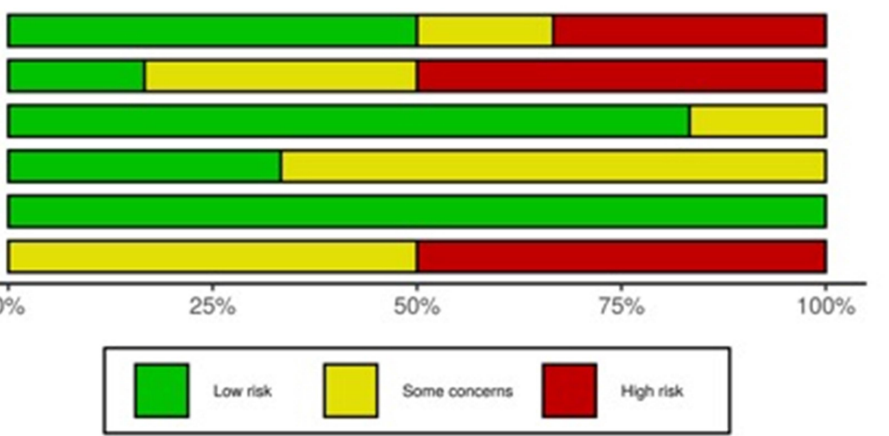

Figure I Assessment of the risk of bias via the Cochrane RoB 2 tool displayed by means of a traffic light plot of the risk of bias of each included clinical study (A), and weighted plot for the distribution of the overall risk of bias within each bias domain via the Cochrane RoB 2 tool (B) ( $n=6$ clinical studies). Traffic light plot reports five risk of bias domains: DI, bias arising from the randomization process; D2, bias due to deviations from intended intervention; D3, bias due to missing outcome data; D4, bias in measurement of the outcome; D5, bias in selection of the reported result; Yellow circle indicates some concerns on the risk of bias and green circle represents low risk of bias.

Note: Figure image was created using https://mcguinlu.shinyapps.io/robvis/.

Abbreviation: RoB, risk of bias. 
antagonists in general, and LAMAs, in particular, may exert significant anti-inflammatory effect from bench-tobedside. Among the approved LAMAs, most of the current evidence on the anti-inflammatory activity in the airways is related to TIO. Evidence demonstrated a reduction in the synthesis and release of cytokines and chemokines, as well as the total and differential number of inflammatory cells, induced by several pro-inflammatory different stimuli such as $\mathrm{ACh}, \mathrm{HCl}, \mathrm{CS}, \mathrm{CdCl}_{2}$, IL-1 $\beta$, LPS, OVA, PHA, RB, TGF- $\beta$, and viral infections. Effectively, it has been thoroughly documented that the mode of action of TIO consists of a bronchodilator effect and reduced mucus secretion. Interestingly, preclinical evidence also suggests an anti-inflammatory effect of TIO. ${ }^{7}$ Conversely, few data are currently available for ACL and GLY, whereas no studies on the potential anti-inflammatory effect of umeclidinium have been reported.

In pre-clinical settings, the most direct way to deliver pulmonary drugs to the target tissue is via intratracheal, intranasal, or aerosol delivery. Although intranasal instillation and nebulization are very different administration techniques, ${ }^{62}$ it has been demonstrated that both are effective at achieving dose-dependent lung deposition and display a comparable systemic exposure. ${ }^{63}$

Interestingly, it has been documented that TIO may increase the percentage of apoptotic CD3+ and CD8+ PBT-cells and reduced the apoptotic CD4+ cells in COPD patients. ${ }^{21}$ This contradictory finding could be explained by a different degree of binding between Ach and $\mathrm{T}$ lymphocytes, therefore it can be hypothesized that muscarinic receptor stimulation regulates the apoptosis and restores the physiological balance between CD4+ and CD8+ PBT-cells. ${ }^{64}$

Paradoxically, long-term treatment with TIO was associated with an increased concentration of IL- 8 and MMP-9 in the sputum of COPD patients. This evidence can be the result of the inhibitory action of TIO exerted on mucussecreting airway goblet cells, thus leading to a reduced amount of mucus secretion and a higher concentration of the mediators in the sputum. ${ }^{59,61}$

In any case, the evidence of this qualitative synthesis supports the current hypothesis that non-neurogenic Ach contributes to airway inflammation via activation of mAchRs. ${ }^{65}$ In fact, multiple pro-inflammatory stimuli can lead to the release of Ach from respiratory epithelial cells, fibroblasts, and inflammatory cells, thus producing various biological reactions in an auto/paracrine manner. ${ }^{66}$
Blockade of muscarinic M3 receptors by LAMA might result in anti-inflammatory effects in the airways; such effects might be increased by the concomitant activation of beta 2 receptors by LABA. ${ }^{13}$ However, clinical studies including airway inflammatory biomarkers in patients with COPD are required to assess these pharmacological effects.

In this respect, the blockage of $\mathrm{M}_{3} \mathrm{mAchR}$ elicited by LAMAs seems to result in anti-inflammatory effects in the airways, which could be synergistically increased by concomitant treatment with LABAs. ${ }^{65}$ Recent evidence further supports the beneficial synergistic interaction at the level of human medium bronchi and small airways not only when TIO is combined with the long-acting $\beta_{2}$ adrenoceptor agonist (LABA) olodaterol (OLO) as LABA/ LAMA fixed-dose combination (FDC), ${ }^{67}$ but also when a LAMA is combined with an inhaled corticosteroid (ICS), ${ }^{68}$ and when ICSs, LABAs and LAMAs are combined in triple FDCs. ${ }^{69}$ Overall, the currently available data on the anti-inflammatory effect of LAMAs support the evidence coming from studies performed ex vivo concerning the release of non-neurogenic Ach in the airways. ${ }^{9}$

The evidence arising from clinical trials specifically designed to assess the anti-inflammatory profile of LAMAs has been focused exclusively on TIO. Certainly, TIO demonstrated short- and long-term anti-inflammatory activity in COPD, although it did not modulate all the proinflammatory investigated outcomes. These clinical studies were performed by administering TIO at $18 \mu \mathrm{g}$ via the HandiHaler device in non-randomized clinical trials. ${ }^{56-61}$ This represents the main limitation of this systematic review, as there is an unmet need to understand whether reaching small airways by delivering TIO at $5 \mu \mathrm{g}$ via Respimat device may further improve the antiinflammatory activity of this LAMA. This is a hypothesis based on the recent evidence from randomized controlled trials (RCTs) that TIO alone, or in combination with an ICS and/or a LABA, is effective in reducing the risk of COPD and asthma exacerbation. ${ }^{70-72}$

In this respect, it seems that $\mathrm{TIO}$ at $5 \mu \mathrm{g}$ via Respimat may lead to ceiling effect that, in turn, may effectively modulate pulmonary inflammation. ${ }^{73}$ The clinical benefit of TIO in reducing the risk of COPD exacerbation is further confirmed by a recent meta-analysis demonstrating that treatment with LAMA in stable COPD produced a lower incidence of exacerbation compared to $\mathrm{LABA}^{74}$ In asthmatic patients, the exploratory analyses conducted by Szefler et $\mathrm{al}^{72}$ and Casale et $\mathrm{al}^{75}$ confirmed the efficacy 
of TIO added to ICSs, with or without other controllers, in improving the frequency of exacerbations.

Probably the anti-inflammatory action of LAMAs is directly accountable for the reduction in the risk of exacerbation. However, although current pre-clinical evidence supports this hypothesis, some studies in COPD patients provided contrasting results. According to Powrie et al. ${ }^{61}$ TIO-induced prevention of COPD exacerbations is rather associated with an improvement in dynamic hyperinflation or airway mucus hypersecretion. As argued by the authors, the main limitation of the study was the use of sputum samples to quantify inflammatory markers, as they are difficult to be obtained and are characterized by high variability in cytokine levels. ${ }^{61}$ Furthermore, TIO could have reduced mucus secretion, thus producing a higher release of mediators in sputum. ${ }^{61}$ Measurement of sputum markers may not be fully reflective of the changes occurring in the bronchial mucosa, ${ }^{76}$ therefore further clinical investigations are needed, especially to identify the appropriate inflammatory markers to measure in bronchial biopsies. $^{77}$

Evidence from experimental models documented that LAMAs reduces mucus production, ${ }^{78}$ and in particular, COPD patients reported a subjective improvement in sputum clearance upon treatment with TIO. ${ }^{61}$ Mucus hypersecretion is indeed an important feature of chronic obstructive respiratory disorders such as COPD and asthma, and contributes to alter the quality of life, morbidity and mortality of patients. ${ }^{79}$

The $\mathrm{M}_{3} \mathrm{mAchR}$ represents the dominant subtype in the regulation of neuronally mediated mucus secretion from submucosal glands and goblet cells, ${ }^{80,81}$ and TIO is, in particular, one of the LAMAs with higher selectivity for this receptor. ${ }^{65}$ MUC5AC gene is the main mucin gene expressed in human airway epithelial cells, ${ }^{79}$ and TIO was reported to reduce the number of MUC5AC-positive goblet cell in a guinea pig model, ${ }^{82}$ mucus gland hypertrophy, ${ }^{32}$ and prevented neutrophil elastase-induced goblet cell metaplasia in mice, ${ }^{83}$ an effect that seemed related to a reduced recruitment of neutrophils in vivo. ${ }^{82,83}$ Indeed, these mechanisms may also contribute to an indirect anti-inflammatory effect leading to clinical benefits.

In any case, recent investigations provide the evidence that TIO $5 \mu \mathrm{g}$ via Respimat is effective in improving lung function, asthma control, and exacerbation risk when given as add-on therapy in children, adolescents, and adult patients independent of the markers of $\mathrm{T} 2$ inflammation, namely total IgE and blood eosinophil counts. ${ }^{72,75}$
Table 5 Search Details for "Respimat" and "Asthma" in the ClinicalTrials.gov Database by Applying the Filters "with Results" and "Interventional" (Last Update July 28th 2020)

\begin{tabular}{|l|l|l|}
\hline $\begin{array}{l}\text { Terms } \\
\text { Synonyms }\end{array}$ & Search Results* & Entire Database** \\
\hline Respimat & 25 studies & 191 studies \\
Asthma & 25 studies & 3778 studies \\
Asthmatic & - & 550 studies \\
\hline
\end{tabular}

Notes: - no studies found, *number of studies in the search results containing the term or synonym; **number of studies in the entire database containing the term or synonym.

Therefore, there is the rational for administering TIO Respimat as add-on therapy with no requirement for phenotyping patients before treatment. ${ }^{72,75}$

Indeed, the scientific interest in TIO in asthma is further proved by the number of RCTs registered in the ClinicalTirals.gov database and reporting results for the efficacy and the safety profile of TIO $5 \mu \mathrm{g}$ via Respimat in children and adolescents (8 studies) and adults (17 studies) patients (Table 5). Considering that Respimat permits to optimize the delivery of TIO $5 \mu \mathrm{g}$ into the small airways, it is expected that the anti-inflammatory effect of TIO via Respimat may be superior to that elicited by TIO via HandiHaler because the non-neuronal cholinergic system, and related inflammation, is prevalent at the level of small airways. ${ }^{9}$ Effectively, across the currently available LAMAs, only TIO mostly $5 \mu \mathrm{g}$ once-daily via Respimat is recommended as an add-on therapy and controller option in asthmatic patients at Steps 4 and 5.

\section{Conclusions}

A large pre-clinical body of evidence supports the beneficial impact of TIO against airway inflammation. Further welldesigned RCTs are needed to better elucidate the antiinflammatory mechanisms leading to the protective effect of LAMAs against the risk of exacerbation via identifying suitable biomarkers. Finally, but not less important, head-tohead comparisons across the approved LAMAs performed in human ex vivo experimental settings via translational research could better characterize the specific antiinflammatory profile of each antimuscarinic agent.

\section{Abbreviations}

Ach, acetylcholine; ACL, aclidinium; AHR, airway hyperresponsiveness; ASM, airway smooth muscle; BALf, bronchoalveolar lavage fluid; BCQB, bencycloquidium bromide; Cch, carbachol; $\mathrm{CdCl} 2$, cadmium chloride; 
COPD, chronic obstructive pulmonary disease; CRP, C-reactive protein; CS, cigarette smoke; CSE, cigarette smoke extract; GLY, glycopyrronium; GM-CSF, granulocyte-macrophage colony-stimulating factor; $\mathrm{HCl}$, hydrochloric acid; HDAC2, histone deacetylase 2; IB, ipratropium bromide; IFN- $\gamma$, interferon-gamma; IкB, inhibitor of $\mathrm{NF}-\kappa \mathrm{B}$; I $\kappa \alpha$, inhibitor kappa kinase alpha; IL, interleukin; $\mathrm{KC} / \mathrm{CXCL} 1$, keratinocyte-derived chemokine; LAMA, long-acting muscarinic receptor antagonist; LPS, lipopolysaccharide; LTB4, leukotriene B4; mAchR, muscarinic acetylcholine receptor; MAC-1, macrophage-1 antigen; MCP-1, monocyte chemoattractant; MIP, macrophage inflammatory protein; MMP, metalloproteinase; NF$\kappa \mathrm{B}$, nuclear factor- $\kappa \mathrm{B}$; NLF, nasal lavage fluid; OVA, ovalbumin; PBT, peripheral blood T; PHA, phytohemagglutinin; PPE, porcine pancreatic elastase; RB, resistive breathing; TGF- $\beta 1$, tumor growth factor-beta 1 ; TIMP, tissue inhibitor of metalloproteinase; TIO, tiotropium bromide; TNF- $\alpha$, tumor necrosis factor-alpha; 4-DAMP, 1,1-dimethyl-4-diphenylacetoxypiperidinium iodide.

\section{Author Contributions}

All authors made a significant contribution to the work reported, whether that is in the conception, study design, execution, acquisition of data, analysis and interpretation, or in all these areas; took part in drafting, revising or critically reviewing the article; gave final approval of the version to be published; have agreed on the journal to which the article has been submitted; and agreed to be accountable for all aspects of the work.

\section{Funding}

Boehringer Ingelheim Italia (Medical Affairs, Milan, Italy) unconditionally supported L.C. exclusively for performing the literature search on the impact of muscarinic receptor antagonists on airway inflammation, regardless of writing a paper and regardless of any potential publication.

\section{Disclosure}

L.C. has participated as an advisor in scientific meetings under the sponsorship of Boehringer Ingelheim and Novartis; received nonfinancial support from AstraZeneca; a research grant partially funded by Chiesi Farmaceutici, Boehringer Ingelheim, Novartis, and Almirall; is or has been a consultant to $\mathrm{ABC}$ Farmaceutici, Edmond Pharma, Zambon, Verona Pharma, and Ockham Biotech; and his department was funded by Almirall, Boehringer Ingelheim, Chiesi Farmaceutici, Novartis, and Zambon.

A.Co. participated as a lecturer and speaker in scientific meetings and courses under the sponsorship of AstraZeneca, Boehringer Ingelheim, GlaxoSmithKline, Menarini Group and Zambon.

B.L.R. has no conflict of interest to declare.

M.M. has no conflict of interest to declare.

A.Ch. received grants from Menarini and Astra Zeneca, and personal fee from Chiesi.

P.R. participated as a lecturer and advisor in scientific meetings and courses under the sponsorship of Almirall, AstraZeneca, Biofutura, Boehringer Ingelheim, Chiesi Farmaceutici, GlaxoSmithKline, Menarini Group, Mundipharma, and Novartis, and her department was funded by Almirall, Boehringer Ingelheim, Chiesi Farmaceutici Novartis, and Zambon.

The authors report no other potential conflicts of interest for this work.

\section{References}

1. Global Initiative for Chronic Obstructive Lung Disease (GOLD). Global strategy for diagnosis, management, and prevention of COPD - 2020 Report. 2020. Available from: https://goldcopd.org/ wp-content/uploads/2019/12/GOLD-2020-FINAL-ver1.2-03Dec19_ WMV.pdf. Accessed July 28, 2020.

2. Global Initiative for Asthma (GINA). Global strategy for asthma management and prevention. 2020. Available from: https:// ginasthma.org/wp-content/uploads/2020/06/GINA-2020report_20_06_04-1-wms.pdf. Accessed July 28, 2020.

3. Holguin F, Cardet JC, Chung KF, et al. Management of severe asthma: a European Respiratory Society/American Thoracic Society guideline. Eur Respir J. 2020;55:1. doi:10.1183/13993003.00588-2019

4. Canning BJ. Reflex regulation of airway smooth muscle tone. J Appl Physiol. 2006;101(3):971-985. doi:10.1152/japplphysiol. 00313.2006

5. Gelb AF, Nadel JA. Affirmation of the adoration of the vagi and role of tiotropium in asthmatic patients. J Allergy Clin Immunol. 2016;138 (4):1011-1013. doi:10.1016/j.jaci.2016.06.024

6. Gosens R, Zaagsma J, Meurs H, Halayko AJ. Muscarinic receptor signaling in the pathophysiology of asthma and COPD. Respir Res. 2006;7:73.

7. Mansfield L, Bernstein JA. Tiotropium in asthma: from bench to bedside. Respir Med. 2019;154:47-55. doi:10.1016/j. rmed.2019.06.008

8. Alagha K, Palot A, Sofalvi T, et al. Long-acting muscarinic receptor antagonists for the treatment of chronic airway diseases. Ther $A d v$ Chronic Dis. 2014;5(2):85-98. doi:10.1177/2040622313518227

9. Cazzola M, Calzetta L, Puxeddu E, et al. Pharmacological characterisation of the interaction between glycopyrronium bromide and indacaterol fumarate in human isolated bronchi, small airways and bronchial epithelial cells. Respir Res. 2016;17(1):70. doi:10.1186/ s12931-016-0386-8

10. Moher D, Shamseer L, Clarke M, et al. Preferred reporting items for systematic review and meta-analysis protocols (PRISMA-P) 2015 statement. Syst Rev. 2015;4(1):1. doi:10.1186/2046-4053-4-1 
11. Jadad AR, Moore RA, Carroll D, et al. Assessing the quality of reports of randomized clinical trials: is blinding necessary? Control Clin Trials. 1996;17(1):1-12. doi:10.1016/0197-2456(95)00134-4

12. Higgins JPT, Savović J, Page MJ, Elbers RG, Sterne JAC. Chapter 8: assessing risk of bias in a randomized trial. Cochrane Handbook for Systematic Reviews of Interventions version 6.0 (updated July 2019). Cochrane, 2019. 2019;205-228. Available from http://www.training. cochrane.org/handbook.

13. Albano GD, Bonanno A, Moscato M, et al. Crosstalk between mAChRM3 and $\beta 2 \mathrm{AR}$, via acetylcholine PI3/PKC/PBEP1/Raf-1 MEK1/2/ERK1/2 pathway activation, in human bronchial epithelial cells after long-term cigarette smoke exposure. Life Sci. 2018;192:99-109. doi:10.1016/j.lfs.2017.11.034

14. Anzalone G, Gagliardo R, Bucchieri F, et al. IL-17A induces chromatin remodeling promoting IL-8 release in bronchial epithelial cells: effect of Tiotropium. Life Sci. 2016;152:107-116. doi:10.1016/j. lfs.2016.03.031

15. Profita M, Bonanno A, Montalbano AM, et al. $\beta 2$ long-acting and anticholinergic drugs control TGF- $\beta 1$-mediated neutrophilic inflammation in COPD. Biochimica Et Biophysica Acta (BBA) Mol Basis Dis. 2012;1822(7):1079-1089. doi:10.1016/j.bbadis.2012.03.002

16. Yamaya $M$, Nishimura $H$, Hatachi $Y$, et al. Inhibitory effects of tiotropium on rhinovirus infection in human airway epithelial cells. Eur Respir J. 2012;40(1):122-132. doi:10.1183/09031936.00065111

17. Suzaki I, Asano K, Shikama Y, Hamasaki T, Kanei A, Suzaki H. Suppression of IL-8 production from airway cells by tiotropium bromide in vitro. Int $J$ Chron Obstruct Pulmon Dis. 2011;6:439-448. doi:10.2147/COPD.S23695

18. Costa L, Roth M, Miglino N, et al. Tiotropium sustains the anti-inflammatory action of olodaterol via the cyclic AMP pathway. Pulm Pharmacol Ther. 2014;27(1):29-37. doi:10.1016/j.pupt.2013. 11.001

19. Asano K, Shikama Y, Shoji N, Hirano K, Suzaki H, Nakajima H. Tiotropium bromide inhibits TGF-beta-induced MMP production from lung fibroblasts by interfering with Smad and MAPK pathways in vitro. Int $J$ Chron Obstruct Pulmon Dis. 2010;5:277-286. doi:10.2147/COPD.S11737

20. Vacca G, Randerath WJ, Gillissen A. Inhibition of granulocyte migration by tiotropium bromide. Respir Res. 2011;12:24. doi:10.1186/ 1465-9921-12-24

21. Profita M, Riccobono L, Montalbano AM, et al. In vitro anticholinergic drugs affect CD8+ peripheral blood T-cells apoptosis in COPD. Immunobiology. 2012;217(3):345-353. doi:10.1016/j.imbio.2011.07.013

22. Ohta S, Oda N, Yokoe T, et al. Effect of tiotropium bromide on airway inflammation and remodelling in a mouse model of asthma. Clin Exp Allergy. 2010;40(8):1266-1275. doi:10.1111/j.1365-2222.20 10.03478.x

23. Ferraro M, Di Vincenzo S, Dino P, et al. Budesonide, Aclidinium and Formoterol in combination limit inflammaging processes in bronchial epithelial cells exposed to cigarette smoke. Exp Gerontol. 2019;118:78-87. doi:10.1016/j.exger.2019.01.016

24. Milara J, Cervera A, de Diego A, et al. Non-neuronal cholinergic system contributes to corticosteroid resistance in chronic obstructive pulmonary disease patients. Respir Res. 2016;17(1):145. doi:10.1186/ s12931-016-0467-8

25. Hsiao Y-H, Tseng C-M, Su K-C, et al. Glycopyrronium bromide inhibits lung inflammation and small airway remodeling induced by subchronic cigarette smoke exposure in mice. Respir Physiol Neurobiol. 2018;249:16-22. doi:10.1016/j.resp.2017.12.005

26. Xu ZP, Yang $\mathrm{K}, \mathrm{Xu} \mathrm{GN}$, et al. Role of $\mathrm{M} 3 \mathrm{mAChR}$ in in vivo and in vitro models of LPS-induced inflammatory response. Int Immunopharmacol. 2012;14(3):320-327. doi:10.1016/j.intimp.2012.07.020

27. Bucher H, Duechs MJ, Tilp C, Jung B, Erb KJ. Tiotropium attenuates virus-induced pulmonary inflammation in cigarette smoke-exposed mice. J Pharmacol Exp Ther. 2016;357(3):606-618. doi:10.1124/ jpet.116.232009
28. Zhang SJ, Jiang JX, Ren QQ, Xie QM, Xiong YK. Effects of the inhalation of the $\mathrm{m} 3$ receptor antagonist bencycloquidium bromide in a mouse cigarette smoke-induced airway inflammation model. Drug Dev Res. 2015;76(3):123-131. doi:10.1002/ddr.21248

29. Shen LL, Liu YN, Shen HJ, et al. Inhalation of glycopyrronium inhibits cigarette smoke-induced acute lung inflammation in a murine model of COPD. Int Immunopharmacol. 2014;18 (2):358-364. doi:10.1016/j.intimp.2013.12.021

30. Wollin L, Pieper MP. Tiotropium bromide exerts anti-inflammatory activity in a cigarette smoke mouse model of COPD. Pulm Pharmacol Ther. 2010;23(4):345-354. doi:10.1016/ j.pupt.2010.03.008

31. Kolahian S, Shahbazfar AA, Tayefi-Nasrabadi H, et al. Tiotropium effects on airway inflammatory events in the cat as an animal model for acute cigarette smoke-induced lung inflammation. Exp Lung Res. 2014;40(6):272-287. doi:10.3109/01902148.2014.905657

32. Pera T, Zuidhof A, Valadas J, et al. Tiotropium inhibits pulmonary inflammation and remodelling in a guinea pig model of COPD. Eur Respir J. 2011;38(4):789-796. doi:10.1183/09031936.00146610

33. John-Schuster G, de Kleijn S, van Wijck Y, et al. The effect of tiotropium in combination with olodaterol on house dust mite-induced allergic airway disease. Pulm Pharmacol Ther. 2017;45:210-217. doi:10.1016/j.pupt.2017.06.010

34. Gregory JA, Kemi C, Ji J, et al. Effects of tiotropium bromide on airway hyperresponsiveness and inflammation in mice exposed to organic dust. Pulm Pharmacol Ther. 2018;48:203-210. doi:10.1016/ j.pupt.2017.12.004

35. Wang J, Diao X, Zhu H, He B. Effect of tiotropium bromide on airway inflammation and programmed cell death 5 in a mouse model of ovalbumin-induced allergic asthma. Can Respir j. 2019; 2019:6462171. doi:10.1155/2019/6462171

36. Cao R, Dong X-W, Jiang J-X, et al. M3 muscarinic receptor antagonist bencycloquidium bromide attenuates allergic airway inflammation, hyperresponsiveness and remodeling in mice. Eur J Pharmacol. 2011;655(1-3):83-90. doi:10.1016/j.ejphar.2011.01.024

37. Kurai J, Watanabe M, Sano H, et al. Reduces airway inflammation and bronchoconstriction induced by ambient particulate matter in a mouse model of asthma. Int $J$ Environ Res Public Health. 2018;15:6. doi:10.3390/ijerph15061189

38. Bosnjak B, Tilp C, Tomsic C, et al. Tiotropium bromide inhibits relapsing allergic asthma in BALB/c mice. Pulm Pharmacol Ther. 2014;27(1):44-51. doi:10.1016/j.pupt.2013.09.004

39. Kang JY, Kim IK, Hur J, et al. Expression of muscarinic receptors and the effect of tiotropium bromide in aged mouse model of chronic asthma. Tuberc Respir Dis (Seoul). 2019;82(1):71-80. doi:10.4046/ $\operatorname{trd} .2018 .0049$

40. Kang JY, Rhee CK, Kim JS, et al. Effect of tiotropium bromide on airway remodeling in a chronic asthma model. Ann Allergy Asthma Immunol. 2012;109(1):29-35. doi:10.1016/j.anai.2012.05.005

41. Kistemaker LE, Bos IS, Menzen MH, Maarsingh H, Meurs H, Gosens R. Combination therapy of tiotropium and ciclesonide attenuates airway inflammation and remodeling in a guinea pig model of chronic asthma. Respir Res. 2016;17:13. doi:10.1186/s12931-0160327-6

42. Smit M, Zuidhof AB, Bos SIT, et al. Bronchoprotection by olodaterol is synergistically enhanced by tiotropium in a guinea pig model of allergic asthma. J Pharmacol Exp Ther. 2014;348(2):303-310. doi:10.1124/jpet.113.208439

43. Buels KS, Jacoby DB, Fryer AD. Non-bronchodilating mechanisms of tiotropium prevent airway hyperreactivity in a guinea-pig model of allergic asthma. Br J Pharmacol. 2012;165(5):1501-1514. doi:10.11 11/j.1476-5381.2011.01632.x

44. Devillier P, Garrigue E, D’Auzers G, Monjotin N, Similowski T, Clerc T. V0162 a new long-acting bronchodilator for treatment of chronic obstructive lung diseases: preclinical and clinical results. Respir Res. 2015;16:68. doi:10.1186/s12931-015-0227-1 
45. Toumpanakis D, Loverdos K, Tzouda V, et al. Tiotropium bromide exerts anti-inflammatory effects during resistive breathing, an experimental model of severe airway obstruction. Int J Chron Obstruct Pulmon Dis. 2017;12:2207-2220. doi:10.2147/COPD.S137587

46. Cui Y, Devillier P, Kuang X, et al. Tiotropium reduction of lung inflammation in a model of chronic gastro-oesophageal reflux. Eur Respir J. 2010;35(6):1370-1376. doi:10.1183/09031936.00139909

47. Zhao S, Yang Q, Yu Z, et al. Protective effects of tiotropium alone or combined with budesonide against cadmium inhalation induced acute neutrophilic pulmonary inflammation in rats. PLoS One. 2018;13(2): e0193610. doi:10.1371/journal.pone.0193610

48. Damera G, Jiang M, Zhao H, et al. Aclidinium bromide abrogates allergen-induced hyperresponsiveness and reduces eosinophilia in murine model of airway inflammation. Eur J Pharmacol. 2010;649 (1-3):349-353. doi:10.1016/j.ejphar.2010.09.043

49. Dominguez-Fandos D, Ferrer E, Puig-Pey R, et al. Effects of aclidinium bromide in a cigarette smoke-exposed Guinea pig model of chronic obstructive pulmonary disease. Am J Respir Cell Mol Biol. 2014;50(2):337-346. doi:10.1165/rcmb.2013-0117OC

50. Long R, Zhou Y, Huang J, et al. Bencycloquidium bromide inhibits nasal hypersecretion in a rat model of allergic rhinitis. Inflammation Res. 2015;64(3-4):213-223. doi:10.1007/s00011-015-0800-6

51. Zhang W, Fievez L, Cheu E, et al. Anti-inflammatory effects of formoterol and ipratropium bromide against acute cadmium-induced pulmonary inflammation in rats. Eur J Pharmacol. 2010;628(1-3):171-178. doi:10.1016/j.ejphar.2009.11.015

52. Zhang W, Fievez L, Zhang F, et al. Effects of formoterol and ipratropium bromide on repeated cadmium inhalation-induced pulmonary inflammation and emphysema in rats. Eur J Pharmacol. 2010;647 (1-3):178-187. doi:10.1016/j.ejphar.2010.08.028

53. Kistemaker LE, Bos IS, Hylkema MN, et al. Muscarinic receptor subtype-specific effects on cigarette smoke-induced inflammation in mice. Eur Respir J. 2013;42(6):1677-1688. doi:10.1183/09031936.00112412

54. Tanaka K, Ishihara T, Sugizaki T, et al. Mepenzolate bromide displays beneficial effects in a mouse model of chronic obstructive pulmonary disease. Nat Commun. 2013;4:2686. doi:10.1038/ ncomms 3686

55. Xu ZP, Wang H, Hou LN, et al. Modulatory effect of anisodamine on airway hyper-reactivity and eosinophilic inflammation in a murine model of allergic asthma. Int Immunopharmacol. 2011;11 (2):260-265. doi:10.1016/j.intimp.2010.12.001

56. Santus P, Buccellati C, Centanni S, et al. Bronchodilators modulate inflammation in chronic obstructive pulmonary disease subjects. Pharmacol Res. 2012;66(4):343-348. doi:10.1016/j.phrs.2012.05.007

57. Ozol D, Karamanli H, Uysal S, Yigitoglu MR, Yildirim Z. Airway inflammation and tiotropium treatment in stable COPD patients. Turkish j Med Sci. 2014;44(5):804-808. doi:10.3906/sag-1303-138

58. Holownia A, Mroz RM, Skopinski T, et al. Tiotropium increases cytosolic muscarinic $\mathrm{M} 3$ receptors and acetylated $\mathrm{H} 3$ histone proteins in induced sputum cells of COPD patients. Eur J Med Res. 2010;15 (Suppl 2):64-67. doi:10.1186/2047-783X-15-S2-64

59. Perng D-W, Tao C-W, Su K-C, Tsai -C-C, Liu L-Y, Lee Y-C. Antiinflammatory effects of salmeterol/fluticasone, tiotropium/fluticasone or tiotropium in COPD. Eur Respir J. 2009;33(4):778-784. doi:10.1183/09031936.00115308

60. Lin Y-H, Liao X-N, Fan -L-L, Qu Y-J, Cheng D-Y, Shi Y-H. Longterm treatment with budesonide/formoterol attenuates circulating CRP levels in chronic obstructive pulmonary disease patients of group D. PLoS One. 2017;12:8.

61. Powrie DJ, Wilkinson TM, Donaldson GC, et al. Effect of tiotropium on sputum and serum inflammatory markers and exacerbations in COPD. Eur Respir J. 2007;30(3):472-478. doi:10.1183/09031936.00023907

62. Fernandes CA, Vanbever R. Preclinical models for pulmonary drug delivery. Expert Opin Drug Deliv. 2009;6(11):1231-1245. doi:10.15 $17 / 17425240903241788$
63. Chiang PC, Alsup JW, Lai Y, Hu Y, Heyde BR, Tung D. Evaluation of aerosol delivery of nanosuspension for pre-clinical pulmonary drug delivery. Nanoscale Res Lett. 2009;4(3):254-261. doi:10.1007/ s11671-008-9234-1

64. Baraldo S, Lokar Oliani K, Turato G, Zuin R, Saetta M. The role of lymphocytes in the pathogenesis of asthma and COPD. Curr Med Chem. 2007;14(21):2250-2256. doi:10.2174/092986707781696573

65. Yamada M, Ichinose M. The cholinergic pathways in inflammation: a potential pharmacotherapeutic target for COPD. Front Pharmacol. 2018;9:1426. doi:10.3389/fphar.2018.01426

66. Koarai A, Ichinose M. Possible involvement of acetylcholine-mediated inflammation in airway diseases. Allergol Int. 2018;67(4):460-466. doi:10.1016/j.alit.2018.02.008

67. Calzetta L, Rogliani P, Page C, Rinaldi B, Cazzola M, Matera MG. Pharmacological characterization of the interaction between tiotropium bromide and olodaterol on human bronchi and small airways. Pulm Pharmacol Ther. 2019;56:39-50. doi:10.1016/j.pupt.2019. 03.004

68. Cazzola M, Calzetta L, Rogliani P, Puxeddu E, Facciolo F, Matera MG. Interaction between corticosteroids and muscarinic antagonists in human airways. Pulm Pharmacol Ther. 2016;36:1-9. doi:10.1016/j.pupt.2015.11.004

69. Rogliani P, Matera MG, Facciolo F, Page C, Cazzola M, Calzetta L. Beclomethasone dipropionate, formoterol fumarate and glycopyrronium bromide: synergy of triple combination therapy on human airway smooth muscle ex vivo. $B r \quad J$ Pharmacol. 2020;177 (5):1150-1163. doi:10.1111/bph.14909

70. Calverley PMA, Anzueto AR, Carter K, et al. Tiotropium and olodaterol in the prevention of chronic obstructive pulmonary disease exacerbations (DYNAGITO): a double-blind, randomised, parallel-group, active-controlled trial. Lancet Respir Med. 2018;6 (5):337-344. doi:10.1016/S2213-2600(18)30102-4

71. Rogliani P, Calzetta L, Cazzola M. Is ICS-LAMA an alternative option to treat patients with COPD? Lancet Respir Med. 2018;6 (5):316-317. doi:10.1016/S2213-2600(18)30139-5

72. Szefler SJ, Vogelberg C, Bernstein JA, et al. Tiotropium is efficacious in 6-to 17-year-olds with asthma, independent of T2 phenotype. J Allergy Clin Immunol Pract. 2019;7(7):2286-2295. doi:10.1016/j. jaip.2019.03.019

73. Benfante A, Braido F, Scichilone N. The anti-inflammatory properties of tiotropium. Lancet Respir Med. 2018;6(8):e37. doi:10.1016/ S2213-2600(18)30190-5

74. Koarai A, Sugiura H, Yamada M, et al. Treatment with LABA versus LAMA for stable COPD: a systematic review and meta-analysis. BMC Pulm Med. 2020;20(1):111. doi:10.1186/ s12890-020-1152-8

75. Casale TB, Bateman ED, Vandewalker M, et al. Tiotropium respimat Add-on is efficacious in symptomatic asthma, independent of T2 phenotype. J Allergy Clin Immunol Pract. 2018;6(3):923-935. doi:10.1016/j.jaip.2017.08.037

76. Bateman ED, Rennard S, Barnes PJ, et al. Alternative mechanisms for tiotropium. Pulm Pharmacol Ther. 2009;22(6):533-542. doi:10.1016/j.pupt.2009.06.002

77. Barnes NC, Qiu YS, Pavord ID, et al. Antiinflammatory effects of salmeterol/fluticasone propionate in chronic obstructive lung disease. Am J Respir Crit Care Med. 2006;173(7):736-743. doi:10.1164/ rccm.200508-13210C

78. Martin C, Frija-Masson J, Burgel PR. Targeting mucus hypersecretion: new therapeutic opportunities for COPD? Drugs. 2014;74 (10):1073-1089. doi:10.1007/s40265-014-0235-3

79. Morcillo EJ, Cortijo J. Mucus and MUC in asthma. Curr Opin Pulm Med. 2006;12(1):1-6. doi:10.1097/01.mcp.0000198064.27586.37

80. Rogers DF. Pharmacological regulation of the neuronal control of airway mucus secretion. Curr Opin Pharmacol. 2002;2(3):249-255. doi:10.1016/S1471-4892(02)00146-7 
81. Gosens R, Zaagsma J, Meurs H, Halayko AJ. Muscarinic receptor signaling in the pathophysiology of asthma and COPD. Respir Res. 2006;7(1):73.

82. Bos IS, Gosens R, Zuidhof AB, et al. Inhibition of allergen-induced airway remodelling by tiotropium and budesonide: a comparison. Eur Respir J. 2007;30(4):653-661. doi:10.1183/09031936.00004907
83. Arai N, Kondo M, Izumo T, Tamaoki J, Nagai A. Inhibition of neutrophil elastase-induced goblet cell metaplasia by tiotropium in mice. Eur Respir J. 2010;35(5):1164-1171. doi:10.1183/09031936. 00040709

\section{Publish your work in this journal}

The International Journal of COPD is an international, peer-reviewed journal of therapeutics and pharmacology focusing on concise rapid reporting of clinical studies and reviews in COPD. Special focus is given to the pathophysiological processes underlying the disease, intervention programs, patient focused education, and self management protocols. This journal is indexed on PubMed Central, MedLine and CAS. The manuscript management system is completely online and includes a very quick and fair peer-review system, which is all easy to use. Visit http://www.dovepress.com/testimonials.php to read real quotes from published authors.

Submit your manuscript here: https://www.dovepress.com/international-journal-of-chronic-obstructive-pulmonary-disease-journal 